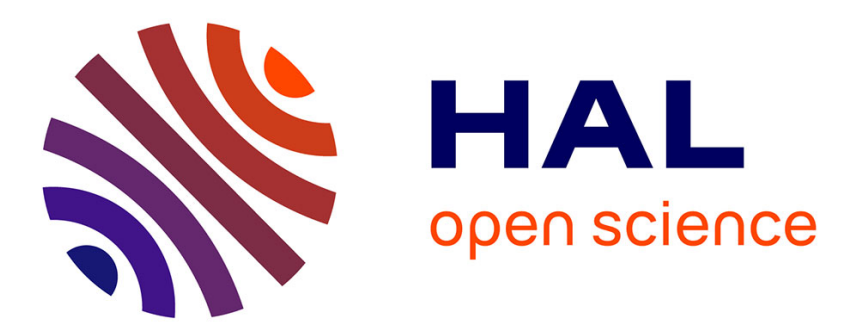

\title{
Protein expression from zooplankton communities in a metal contaminated NW mediterranean coastal ecosystem
}

\author{
Natacha Jean, Estelle Dumont, Gaël Durrieu, Thierry Balliau, Jean-Louis \\ Jamet, Sébastien Personnic, Cédric Garnier
}

\section{To cite this version:}

Natacha Jean, Estelle Dumont, Gaël Durrieu, Thierry Balliau, Jean-Louis Jamet, et al.. Protein expression from zooplankton communities in a metal contaminated NW mediterranean coastal ecosystem. Marine Environmental Research, 2012, 80, pp.12-26. 10.1016/j.marenvres.2012.06.004 . hal01096852

\section{HAL Id: hal-01096852 \\ https://hal-univ-tln.archives-ouvertes.fr/hal-01096852}

Submitted on 5 Jan 2015

HAL is a multi-disciplinary open access archive for the deposit and dissemination of scientific research documents, whether they are published or not. The documents may come from teaching and research institutions in France or abroad, or from public or private research centers.
L'archive ouverte pluridisciplinaire HAL, est destinée au dépôt et à la diffusion de documents scientifiques de niveau recherche, publiés ou non, émanant des établissements d'enseignement et de recherche français ou étrangers, des laboratoires publics ou privés. 
Provided for non-commercial research and education use. Not for reproduction, distribution or commercial use.

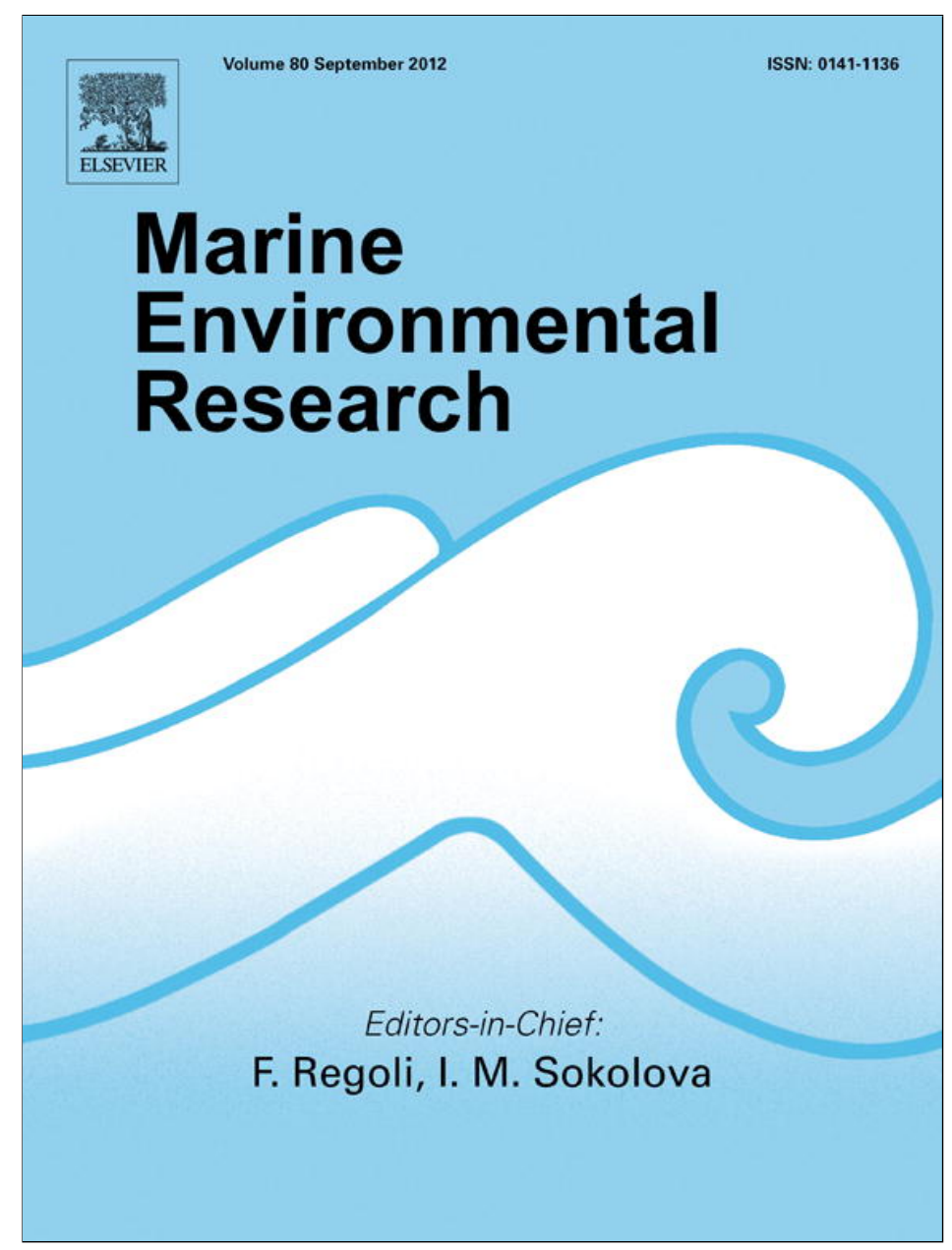

This article appeared in a journal published by Elsevier. The attached copy is furnished to the author for internal non-commercial research and education use, including for instruction at the authors institution and sharing with colleagues.

Other uses, including reproduction and distribution, or selling or licensing copies, or posting to personal, institutional or third party websites are prohibited.

In most cases authors are permitted to post their version of the article (e.g. in Word or Tex form) to their personal website or institutional repository. Authors requiring further information regarding Elsevier's archiving and manuscript policies are encouraged to visit:

http://www.elsevier.com/copyright 


\title{
Protein expression from zooplankton communities in a metal contaminated NW mediterranean coastal ecosystem
}

\author{
Natacha Jean ${ }^{\mathrm{a}, *}$, Estelle Dumont ${ }^{\mathrm{a}}$, Gael Durrieu ${ }^{\mathrm{a}}$, Thierry Balliau ${ }^{\mathrm{b}}$, Jean-Louis Jamet ${ }^{\mathrm{a}}$, \\ Sébastien Personnic ${ }^{a}$, Cédric Garnier ${ }^{\mathrm{a}}$ \\ a Laboratoire Processus de Transfert et d'Echanges dans l'Environnement (EA 3819), Université du Sud Toulon - Var, BP 20132,83957 La Garde Cedex, France \\ ${ }^{\mathrm{b}}$ Plate-forme d'Analyse Protéomique Paris Sud-Ouest, INRA, Unité Mixte de Recherche en Génétique Végétale (UMR 320), Ferme du Moulon, 91 190 Gif-sur-Yvette, France
}

\section{A R T I C L E I N F O}

\section{Article history:}

Received 20 July 2011

Received in revised form

4 May 2012

Accepted 7 June 2012

\section{Keywords:}

Bidimensional polyacrylamide gel

electrophoresis

Monodimensional polyacrylamide gel

electrophoresis

Liquid chromatography tandem mass

spectrometry

Metaproteomics

Trace metals

Zooplankton

Oithona nana

\begin{abstract}
A B S T R A C T
Bidimensional and monodimensional polyacrylamide gel electrophoresis were used to study protein expression from zooplankton collected in thirteen stations of Toulon Bay (NW Mediterranean). In this ecosystem, Little Bay showed higher trace metal concentrations (13.5-23.8 nM for $\mathrm{Cu}, 0.73-1.24 \mathrm{nM}$ for $\mathrm{Pb}, 27.8-58.7 \mathrm{nM}$ for $\mathrm{Zn}$ ) than Large Bay ( $\mathrm{Cu} 2.2-15.6 \mathrm{nM}$; Pb 0.19-0.78 nM; Zn 9.0-38.8 nM). Trace metals positively correlated $(p<0.05)$ with expression of four zooplankton proteins (MW in $\mathrm{kDa} / \mathrm{pI}$ : 25.0/5.6; 48.8/4.1; 38.2/4.4; 38.3/5.8) and with biomass of Oithona nana, predominant copepod in Little Bay. Sequencing by LC-MS/MS putatively provided zooplankton identity of these proteins: they were cytoskeleton actin, except one protein that was the chaperone calreticulin. We suggest that actin and calreticulin could be regarded as zooplankton markers of metal stress and be involved in a possible tolerance of $O$. nana to contamination, contributing to its development in a marine perturbed ecosystem.
\end{abstract}

(c) 2012 Elsevier Ltd. All rights reserved.

\section{Introduction}

Recently, many authors have mentioned the relevance of investigating the new field of marine proteomics (Johnson and Browman, 2007; Lopez, 2007; Nunn and Timperman, 2007). This field presents two coexisting approaches: the first involves analysing proteins from microorganisms cultured under specific

Abbreviations: AFDW, ash-free dry weight; BSA, bovine serum albumin; 2-DE, bidimensional polyacrylamide gel electrophoresis; DOC, dissolved organic carbon; DOM, dissolved organic matter; DW, dry weight; ER, endoplasmic reticulum; HSP heat shock protein; HPLC, high performance liquid chromatography; IPG, immobilized pH gradient; IEF, isoelectric focusing; pI, isolectric point; LC-MS/MS, liquid chromatography tandem mass spectrometry; MW, molecular weight; 1 -DE, monodimensional polyacrylamide gel electrophoresis; NCBI, National Centre for Biotechnology Information; POM, particulate organic matter; ROS, reactive oxygen species; SDS-PAGE, sodium dodecylsulfate polyacrylamide gel electrophoresis.

* Corresponding author. Tel.: +33 4941425 29; fax: +33 494142168.

E-mail addresses: jean@univ-tln.fr (N. Jean), estelle.dumont@univ-tln.fr (E. Dumont),durrieu@univ-tln.fr (G. Durrieu), balliau@moulon.inra.fr (T. Balliau), jamet@univ-tln.fr (J.-L. Jamet), sebastien.personnic@univ-tln.fr (S. Personnic), cgarnier@univ-tln.fr (C. Garnier). environmental conditions, the second involves the recovery and analysis of proteins directly sampled from the marine environment (Nunn and Timperman, 2007). According to the first approach, some studies have been carried out on pure cultures of marine microorganisms such as the bacterium Pseudomonas fluorescens (Poirier et al., 2008), the cyanobacterium Prochlorococcus marinus (Pandhal et al., 2007), the phytoplankton Alexandrium (Chan et al., 2005, 2006; Lee and Lo, 2008; Wang et al., 2008), Prorocentrum (Chan et al., 2002, 2004), Lingulodinium polyedrum (Akimoto et al., 2004), and the zooplankton Calanus finmarchicus (Hansen et al., 2007). According to the second approach, proteomic studies have taken place in marine environments to sample targeted organisms, such as the zooplankton species Acartia tonsa (Tartarotti and Torres, 2009) and Eurytemora affinis (Kimmel and Bradley, 2001), as the fish Paralichthys olivaceus (Ling et al., 2009; Zhu et al., 2006) or the bivalve Mytilus (Manduzio et al., 2005; Mosquera et al., 2003; Ronzitti et al., 2008).

However, it may be assumed that the many species composing a high-complexity community constitute a metaorganism, in which metaproteome shifts could be regarded as a functional response to the dynamic changes affecting the environment (Lacerda et al., 
2007; Wilmes and Bond, 2004). In this way, very recent studies have focused on the metaproteomics characterization of the dissolved organic matter (DOM) and the particulate organic matter (POM) sampled in the South China Sea (Dong et al., 2010; Wang et al., 2011).

Proteomics provides an excellent tool to analyse changes in protein expression in response to contaminant exposure (Andacht and Winn, 2006). Now, coastal marine ecosystems are increasingly exposed to contamination, among which pollution by metals is a serious threat due to their persistence and toxicity towards marine organisms (Huang et al., 2005). Although zooplankton represent a point of entry of contaminants into the food web, through grazing on phytoplankton, and being themselves an important prey for fish (Hansen et al., 2007), few studies have assessed effects of contaminants on zooplankton communities.

Here, we present the first metaproteomics study characterising protein expression from zooplankton communities in a coastal marine ecosystem contaminated by trace metals. We used monodimensional gel electrophoresis (1-DE) and bidimensional polyacrylamide gel electrophoresis (2-DE) to detect shifts in protein expression, from zooplankton sampled in thirteen stations of Toulon Bay (France). We then related the protein shifts to the structure of the zooplankton communities, and to the trace metal concentrations measured in this ecosystem. Our goal was to understand how the zooplankton protein expression changed according to the metal contamination of a marine natural environment. This was to (i) define zooplankton protein markers of metal stresses, (ii) identify stress proteins potentially involved in the tolerance of some zooplankton species to contamination, (iii) understand the potential contribution of some proteins in the changes in zooplankton diversity recurrently observed in the perturbed Toulon Bay (Jamet et al., 2001, 2005; Richard and Jamet, 2001).

\section{Material and methods}

\subsection{Sampling site}

On June 11th 2009, seawater and zooplankton have been sampled in thirteen stations $-\mathrm{S}_{1}$ to $\mathrm{S}_{13}$ - of Toulon Bay, on the NW Mediterranean French coast (Fig. 1). Thanks to a sea wall, Toulon Bay is divided in two smaller bays: Large Bay (LaB) in the south-east (maximal depth: $17 \mathrm{~m}$ ), with sampling stations $\mathrm{S}_{1}-\mathrm{S}_{9}$, and Little
Bay (LiB) in the north-west (maximal depth: $12 \mathrm{~m}$ ), with sampling stations $\mathrm{S}_{10}-\mathrm{S}_{13}$.

LiB, semi-closed with a surface area of $11 \mathrm{~km}^{2}$, harbours major commercial traffic as well as a military port (French Navy). Through the Las river, the first river crossing Toulon city, anthropogenic inputs from the urbanized Toulon area (population density = approximatively 600000 inhabitants) flow into LiB. This ecosystem is significantly polluted, as shown by the high trace metal concentrations measured in Mytilus during the 'Mussel Watch Programme' carried out by the Réseau d'Observation de la Contamination Chimique: $7.26 \mathrm{mg} \mathrm{Pb}$ per $\mathrm{kg}$ of dry weight (4.4 times the national media of $1.65 \mathrm{mg}$ per $\mathrm{kg}$ of dry weight) and $0.54 \mathrm{mg} \mathrm{Hg}$ per $\mathrm{kg}$ of dry weight (3.6 times the national media of $0.15 \mathrm{mg}$ per kg of dry weight) (Ifremer, 2010). In LiB, the macrophyte Posidonia oceanica has disappeared for thirty years (Bernard et al., 2001). The proliferation of harmful phytoplankton species Dinophysis and Pseudo-nitzschia occurs at some periods of the year (Ifremer, 2010). The dominance and high abundance of the Cyclopoid Copepod Oithona nana have been previously reported there, resulting in lower zooplankton diversity (Jamet et al., 2005).

Unlike $\mathrm{LiB}, \mathrm{LaB}$ is connected to the open-sea, the renewal of its water masses being provided by the deep northwest to southeast current, and then by the Liguro-Provençal drift. LaB receives anthropogenic inputs carried by the Eygoutier, the second river passing through Toulon. Compared to the Las, the Eygoutier is regularly dry in summer, suggesting that it contributes less to the pollution of $\mathrm{LaB}$. A recent study reported that sediments were less impacted by metals in LaB than in LiB (Tessier et al., 2011). Great meadows of $P$. oceanica (surface $=325$ ha) and low occurrences of harmful phytoplankton species confirm that LaB is less affected by anthropogenic activities than LiB.

\subsection{Sampling procedures}

All samplings were carried out in $\mathrm{LaB}\left(\mathrm{S}_{1}-\mathrm{S}_{9}\right)$ and in $\mathrm{LiB}$ $\left(S_{10}-S_{13}\right)$ (Fig. 1) on June 11th 2009.

Zooplankton samples were collected using a nylon net (HydroBios, model Apstein) with $90 \mu \mathrm{m}$ mesh $(0.5 \mathrm{~m}$ mouth diameter, $2.5 \mathrm{~m}$ length), equipped with a flowmeter (Hydro-Bios, model 438 110). Each zooplankton sample had a volume ranging from 1.0 to $1.6 \mathrm{~L}$ and came from a filtration of volumes comprised between 7.5 and $10.7 \mathrm{~m}^{3}$ of seawater.

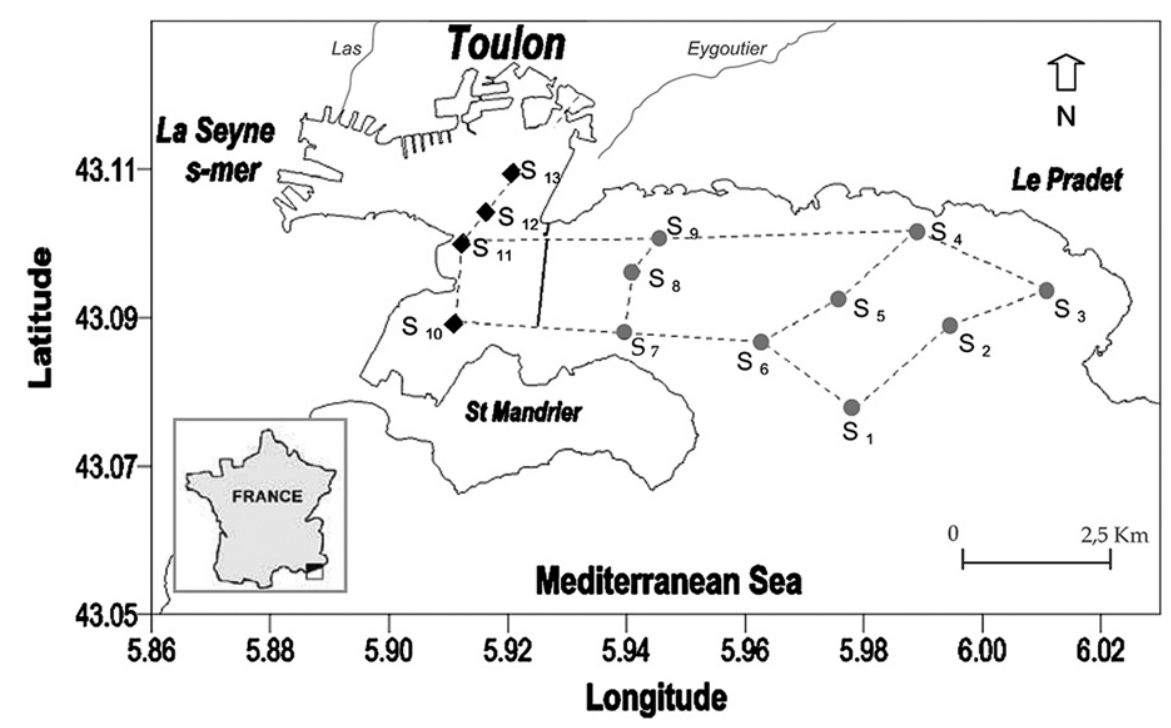

Fig. 1. Location of the $S_{1}-S_{9}$ sampling stations in the Large Bay of Toulon (O), and the $S_{10}-S_{13}$ stations in the Little Bay of Toulon ( $\bullet$ ). 
Seawater samples for total dissolved trace metal analysis were taken at $3 \mathrm{~m}$ depth by scubadiving in precleaned $1 \mathrm{~L}$ Fluorinated Ethylene Propylene (FEP) bottles (Nalgene) and stored in a coolbox until the filtration. Then, samples were filtered through $0.45 \mu \mathrm{m}$ pre-cleaned cellulose nitrate filters (Sartorius), and stored at $4{ }^{\circ} \mathrm{C}$ in the dark until analysis in pre-cleaned $60 \mathrm{~mL}$ FEP (Nalgene) for trace metal measurements (preservation by acidification at $\mathrm{pH}<2$ ). For logistic reasons, no seawater sampling for dissolved trace metal analysis was carried out in $S_{12}$.

\subsection{Preparation of protein extracts}

At the laboratory, zooplankton samples were immediately filtered through Whatman $\mathrm{GF} / \mathrm{C}$ glass fibre filters $(\varnothing=47 \mathrm{~mm})$ to collect the zooplankton individuals. The filters with zooplankton were kept frozen at $-30{ }^{\circ} \mathrm{C}$ overnight and then, lyophilized with a Heto Power Dry LL 1500 Lyophilizator (Thermo Electro Corporation), as recommended for studying proteins in plankton (Tanoue, 1996). Then, surface of the filter was carefully peeled off together with a small amount of glass fibre and finely powdered using a mortar and pestle. The powdered zooplankton samples were immediately extracted, or kept frozen at $-30^{\circ} \mathrm{C}$ until extraction.

\subsubsection{1-DE extraction}

Proteins for 1-DE were extracted according to Tanoue et al. (1996), by homogenizing $0.1 \mathrm{~g}$ of zooplankton powder in $1 \mathrm{~mL}$ of

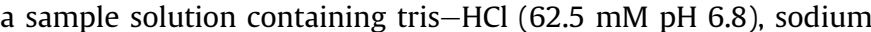
dodecylsulfate (SDS, $2 \% \mathrm{w} / \mathrm{v}$ ), bromophenol blue (BPB, $0.1 \% \mathrm{w} / \mathrm{v}$ ) and 2-mercaptoethanol $(5 \% \mathrm{v} / \mathrm{v})$, and then heated at $100{ }^{\circ} \mathrm{C}$ for $3 \mathrm{~min}$. After cooling, urea was added ( $8 \mathrm{M}$, final concentration) to facilitate the solubilization of zooplankton proteins. After centrifugation at $2000 \times \mathrm{g}$ for $5 \mathrm{~min}$, the supernatant was adjusted to $\mathrm{pH}$ 6.8 with $\mathrm{HCl}$, to obtain the definitive protein extract from which protein determination and 1-DE were achieved.

\subsubsection{2-DE extraction}

Proteins for 2-DE were differently extracted, according to a modified method of Saijo and Tanoue (2004), more intensive than that used for 1-DE. Indeed, a fraction of $0.1 \mathrm{~g}$ of zooplankton powder was homogenized with $1 \mathrm{~mL}$ of a sample solution consisting of urea (7 M), thiourea (2 M), 3-[3-(cholamidopropyl)-dimethylammonio]1-propanesulfonate (CHAPS, $1 \% \mathrm{w} / \mathrm{v}$ ), polyethyleneglycol p-teroctylphenylether (Triton X-100, 3\% v/v), dithiothreitol (DTT, 1\% w/v), carrier ampholytes $(0.2 \% \mathrm{v} / \mathrm{v})$, BPB $(0.002 \% \mathrm{v} / \mathrm{v})$. The mixture was incubated for $1 \mathrm{~h}$ with stirring for $30 \mathrm{~s}$ every $15 \mathrm{~min}$, and was then submitted to centrifugation at $3000 \times \mathrm{g}$ for $30 \mathrm{~min}$. Two freezing-thawing cycles $\left(-30{ }^{\circ} \mathrm{C} /+20{ }^{\circ} \mathrm{C}\right)$ were applied to the obtained supernatant. To complete cell disruption, this was sonicated in an ice-water bath, using a microtip Vibra cell 73424 (Bioblock Scientific) during $5 \mathrm{~min}$, at $20 \mathrm{kHz}$ and $50 \mathrm{~W}$, with $10 \mathrm{~s}$ on/10 s off cycles. The final protein extract was centrifugated at $3000 \times \mathrm{g}$ for $30 \mathrm{~min}$. Protein determination and 2-DE were achieved from the supernatant.

\subsection{Protein determination}

Protein determination of the extracts was achieved according to Lowry et al. (1951), using the Reagent Compatible Detergent Compatible Protein Assay (RC DC Protein Assay, Bio-Rad) and bovine serum albumin (BSA) as standard.

\section{5. $1-D E$}

1-DE was performed as described by Laemmli (1970), using handmade polyacrylamide mini-gels $(10 \mathrm{~cm} \times 7 \mathrm{~cm} \times 1.5 \mathrm{~mm}$, stacking gel: $5 \%$, resolving gel: $11 \%)$. Proteins of a same extract were resolved in triplicate (or in duplicate for $S_{1}, S_{2}, S_{3}$ extracts), by loading three sample volumes containing $100 \mu \mathrm{g}$ zooplankton protein each, in three different wells. A volume of $10 \mu \mathrm{L}$ of a molecular weight marker solution (15-250 kDa range, Precision Plus Protein Standards Dual Color, Bio-Rad) was loaded at the left top of the gel. The gels were run in a Mini-PROTEAN 3 Cell (BioRad) at $+4{ }^{\circ} \mathrm{C}$, under $100 \mathrm{~V}$ and $20 \mathrm{~mA}$ per gel for $10 \mathrm{~min}$, and then, under $150 \mathrm{~V}$ and $40 \mathrm{~mA}$ per gel, until the dye reached the bottom of the gel. Then, gels were stained with Coomassie Brilliant Blue (CBB) R-250 (Bio-Rad), and destained with an acetic acid $(7 \% \mathrm{v} / \mathrm{v})$-ethanol $(5 \% \mathrm{v} / \mathrm{v})$ solution, until visualization of separated protein bands.

The protein bands on the gels were analysed using the Quantity One 1D-Analysis software 4.6.7. version (Bio-Rad). All $R_{\mathrm{f}}$ (relative migration distance run by a protein band) values have been converted into $\log (\mathrm{MW})$ to calculate the MW in each lane of the gels. Intensity of each zooplankton protein band has been calculated as a percentage of the intensity of the $250 \mathrm{kDa}$ marker band.

\section{6. $2-D E$}

Isoelectric focusing (IEF) was carried out according to O'Farrell (1975). The IEF needed pre-prepared immobilized $\mathrm{pH}$ gradient (IPG) strip (17 cm length, linear gradient, $\mathrm{pH} 3-10$, Bio-Rad), under which a sample $(350 \mu \mathrm{L})$ containing $300 \mu \mathrm{g}$ zooplankton protein, was transferred. Rehydration and subsequent IEF of the sample were performed in the horizontal electrophoresis system PROTEAN IEF Cell (Bio-Rad), in the following manner: $18 \mathrm{~h}$ at $50 \mathrm{~V}$ (active rehydration), $2 \mathrm{~h}$ at $100 \mathrm{~V}, 2 \mathrm{~h}$ at $250 \mathrm{~V}, 2 \mathrm{~h}$ at $500 \mathrm{~V}, 2 \mathrm{~h}$ at $1000 \mathrm{~V}$, $2 \mathrm{~h}$ at $4000 \mathrm{~V}$ and $5 \mathrm{~h}$ at $10000 \mathrm{~V}$, so as to reach a total minimal value of $60000 \mathrm{~V}$ h for each loaded IPG strip. All steps were run at $+20^{\circ} \mathrm{C}$. After focusing, the IPG strip was successively equilibrated for $10 \mathrm{~min}$ at room temperature in equilibration buffers 1 (urea $6 \mathrm{M}$, SDS $2 \% \mathrm{w} / \mathrm{v}$, tris $-\mathrm{HCl} 0.375 \mathrm{M} \mathrm{pH} 8.8$, glycerol $20 \% \mathrm{v} / \mathrm{v}$, DTT, $2 \% \mathrm{w} / \mathrm{v}$ ) and 2 (urea $6 \mathrm{M}$, SDS $2 \% \mathrm{w} / \mathrm{v}$, tris- $\mathrm{HCl} 0.375 \mathrm{M} \mathrm{pH} 8.8$, glycerol $20 \%$ $\mathrm{v} / \mathrm{v}$, iodoacetamide $2.5 \% \mathrm{w} / \mathrm{v}$ ).

Sodium dodecylsulfate polyacrylamide gel electrophoresis (SDS-PAGE) was performed according to Laemmli (1970). The equilibrated IPG strip was placed in dyed (BPB) melted agarose, across a handmade polyacrylamide gel $(18 \mathrm{~cm} \times 18 \mathrm{~cm} \times 1 \mathrm{~mm}$, stacking gel: $5 \%$, resolving gel: $11 \%)$. A volume of $20 \mu \mathrm{L}$ of molecular weight marker solution (10-250 kDa range, Precision Plus Protein Standards Dual Color, Bio-Rad) was loaded at the left top of the gel. The gels were run at $+4{ }^{\circ} \mathrm{C}$ in a Protean II XL (Bio-Rad), with a constant current of $20 \mathrm{~mA}$ per gel for $1 \mathrm{~h}$ and then, with a constant current of $30 \mathrm{~mA}$ per gel until the dye reached the bottom of the gel. After electrophoresis, the gels were stained as described in Section 2.5. The 2D-gels presented in this study were representative of two gels performed with the same sample, using an identical extraction procedure but independent 2-DE experiments.

The protein spots on the gels were analysed using the PD-Quest 2D-Analysis software 8.0.1. version (Bio-Rad). Intensity of each zooplankton protein spot has been calculated as a percentage of the total intensity from the marker bands.

\subsection{Protein identification by liquid chromatography tandem mass spectrometry}

In-gel digestion of the picked 2-D spots was performed with the Progest system (Genomic Solution) according to a standard trypsin protocol (Page et al., 2010).

HPLC was performed on a NanoLC-Ultra system (Eksigent). A $4 \mu \mathrm{L}$ sample of the peptide solution was loaded at $7.5 \mu \mathrm{L} \mathrm{min}{ }^{-1}$ on 
a precolumn cartridge (stationary phase: C18 Biosphere, $5 \mu \mathrm{m}$; column: $100 \mu \mathrm{m}$ inner diameter, $2 \mathrm{~cm}$; Nanoseparations) and desalted with $0.1 \% \mathrm{HCOOH}$. After $3 \mathrm{~min}$, the precolumn cartridge was connected to the separating PepMap C18 column (stationary phase: C18 Biosphere, $3 \mu \mathrm{m}$; column: $75 \mu \mathrm{m}$ inner diameter, $150 \mathrm{~mm}$; Nanoseparations). Buffers A and B respectively were prepared with $0.1 \% \mathrm{HCOOH}$ in water, and with $0.1 \% \mathrm{HCOOH}$ in acetonitrile. The peptide separation was achieved with a linear gradient from 5 to $30 \% \mathrm{~B}$ for $28 \mathrm{~min}$ at $300 \mathrm{~nL} \mathrm{~min}^{-1}$. Including the regeneration step at $95 \% \mathrm{~B}$ and the equilibration step at $95 \% \mathrm{~A}$, one run took 45 min.

Eluted peptides were on-line analysed with an LTQ XL ion trap (Thermo Electron) using a nanoelectrospray interface. Ionization (1.5 kV ionization potential) was performed with liquid junction and a non-coated capillary probe $(10 \mu \mathrm{m}$ inner diameter; New Objective). Peptide ions were analysed using Xcalibur 2.07 with the following data-dependent acquisition steps: (1) full MS scan (massto-charge ratio $(m / z) 300-1400$, centroid mode) and (2) MS/MS $\left(q_{z}=0.25\right.$, activation time $=30 \mathrm{~ms}$, and collision energy $=35 \%$; centroid mode). Step 2 was repeated for the three major ions detected in step 1. Dynamic exclusion was set to $30 \mathrm{~s}$.

A database search was performed with XTandem (version 2010.12.01.1) (http://www.thegpm.org/TANDEM/). Enzymatic cleavage was declared as a trypsin digestion with one possible miscleavage. Cys carboxyamidomethylation and Met oxidation were set to static and possible modifications, respectively. Precursor mass and fragment mass tolerance were 2.0 and 0.8 , respectively. A refinement search was added with similar parameters except that semi-trypsic peptide and possible $\mathrm{N}$-ter proteins acetylation were searched. The UniprotKB database (http://www. uniprot.org/) restricted to Metazoa excepted Mammalia (1755330 entries, version 201201), and a contaminant database (trypsin, keratins...) were used. Only peptides with an $E$ value smaller than 0.1 were reported.

Identified proteins were filtered and grouped using XTandem Pipeline (http://pappso.inra.fr/bioinfo/xtandempipeline/) according to: (1) A minimum of two different peptides required with an $E$ value smaller than $0.05,(2)$ a protein $E$ value (calculated as the product of unique peptide $E$ values) smaller than $10^{-4}$. In the case of identification with only two or three MS/MS spectra, similarity between the experimental and the theoretical MS/MS spectra was visually checked.

Identification by database searching was completed by a de novo approach. Peptides sequences were determined by automatic de novo interpretation from MS/MS spectra, using PepNovo software (version 2010225) (1). This analysis was performed on MS/MS spectra with a quality score smaller than 0.1 . Trypsin digestion, Cys carboxyamidomethylation and Met oxidation were set to enzymatic cleavage, static and possible modifications, respectively. Only sequences with a score greater than 70 were selected.

Homology searches were performed by Fasts software (version 36.06) using the MD20-MS matrix (2). Sequences corresponding to keratins or trypsin were firstly removed by interrogating a homemade contaminant database. Secondly, the search computing process was carried out on the same database. Only homologies with a minimum of 2 independent peptides and an $E$ value smaller than 0.001 were selected. In any case, the automatic de novo interpretation of MS/MS spectra was visually confirmed. After searching in the National Centre for Biotechnology Information (NCBI) protein database (http://www.ncbi.nlm.nih.gov/) for sequence comparison and theoretical $\mathrm{MW} / \mathrm{pI}$, identified proteins were classified according to their biological functions with the Funcat automatic classification (http://www.helmholtz-muenchen. de/en/mips/projects/funcat/).

\subsection{Zooplankton counts and biomasses}

In the laboratory, $250 \mathrm{~mL}$ from each zooplankton sample collected with the net was preserved in seawater buffered with $5 \%$ formaldehyde and studied for counts from $1 \mathrm{~mL}$ aliquots taken with a Hensen pipette. A minimum of 250 organisms per each aliquot was identified at the species level, if possible. All zooplankton organisms were enumerated using an inverted microscope at a magnification of $100 \times$. Biomasses were calculated as dry weight (DW, in $\mu \mathrm{g})$ for each zooplankton species, using abundances and length-weight regression equations (Table S1 of Appendix). For the Cladoceran Evadne nordmanii and the Cirripede nauplii, biomasses were calculated from the individual carbon weights $(W$, in $\mu \mathrm{g} C)$ of 2 and $2.5 \mu \mathrm{g} \mathrm{C}$, respectively (Rodhouse and Roden, 1987). The $W$ values were converted to DW assuming a carbon content of 0.5 (Omori, 1969). Ash-free dry weights (AFDW, in $\mu \mathrm{g}$ ) reported in the literature were converted to DW assuming an ash content of 6.4\% AFDW (Chisholm and Roff, 1990). Diversity of the zooplankton communities has been estimated thanks to the Shannon Index $\left(\mathrm{H}^{\prime}\right)$ (Shannon and Weaver, 1949), calculated using the following formula:

$H^{\prime}=-\sum_{i=1}^{S} f_{i} \times \log _{2} f_{i}$

where $f_{i}$ is the frequency of the species $i$.

\subsection{Total dissolved trace metals}

Total dissolved metal concentrations were determined in acidified and UV-digested samples ( $2 \mathrm{~h}$ in quartz tubes on the Metrohm 705 UV Digester) by Differential Pulse Anodic Stripping Voltammetry (DPASV). Measurements were carried out with a voltammetric analyser $\mu$ AutolabIII (Eco Chemie) controlled by GPES 4.9 software (Eco Chemie) coupled with a three-electrode cell of 663 VA Stand (Metrohm) (Louis et al., 2009a). Parameters of the DPASV procedures were adapted from Omanović et al. (2006). Briefly, a first procedure (DPASV1) was adapted for the simultaneous measurement of $\mathrm{Cd}, \mathrm{Cu}$ and $\mathrm{Pb}$ with the following parameters: $300 \mathrm{~s}$ of deposition at $-1.1 \mathrm{~V}$ followed by $10 \mathrm{~s}$ of equilibrium time before the anodic scan from -0.75 to $0 \mathrm{~V}$, all others parameters similar to Omanović et al. (2006). A second procedure (DPASV2) was adapted for $\mathrm{Zn}$ measurement, with $120 \mathrm{~s}$ of deposition at $-1.2 \mathrm{~V}$ followed by $10 \mathrm{~s}$ of equilibrium time before the anodic scan from -1.05 to $-0.75 \mathrm{~V}$. Total dissolved metal concentrations were determined by a fully automated standard addition method. $\mathrm{Cd}, \mathrm{Cu}$ and $\mathrm{Pb}$ concentrations were determined by duplicate DPASV1 measurements on the unspiked sample followed by four additions (using Cavro XL 3000 Syringe Pump) of a $50 \mathrm{nM} \mathrm{Cd}$, $200 \mathrm{nM} \mathrm{Pb}$ and $5 \mu \mathrm{M}$ Cu standard solution. Then, $200 \mu \mathrm{L}$ of a $4 \mathrm{M}$ sodium acetate solution are added to increase the $\mathrm{pH}$ to 4 . Finally, $\mathrm{Zn}$ concentration is determined by duplicate DPASV2 measurements followed by four additions of a $5 \mu \mathrm{M} \mathrm{Zn}$ standard solution.

This analytical procedure was applied to the analysis of $\mathrm{Cd}, \mathrm{Cu}$, and $\mathrm{Zn}$ total dissolved concentrations in certified seawater (CASS-5, NRCCNRC, Cd: $0.19 \pm 0.02 \mathrm{nM}, \mathrm{Cu}: 5.98 \pm 0.44 \mathrm{nM}, \mathrm{Zn}: 11.0 \pm 1.0 \mathrm{nM}$ ), leading to results within the certified limits. In this certified seawater, $\mathrm{Pb}$ determination was not achieved with the $300 \mathrm{~s}$ of deposition time used, due to the extremely low certified value $(0.053 \pm 0.010 \mathrm{nM})$, at least 10 times lower than values measured in our samples.

\subsection{Statistical analysis}

The non-parametric Spearman's rank correlation test (Statistica 7.1. version) was used to compare the data series (protein spot and 
band intensities, zooplankton biomasses, trace metal concentrations). Correlations and relations, characterized by the Spearman's rank correlation coefficient (Spearman's rho, here noted $r$ ), and by $p$ values, were considered as significant if $p<0.05$ (for correlations) or $0.05<p<0.10$ (for relations).

\section{Results}

\subsection{Protein expression}

Despite the strong background staining each lane of the 1Dgels, few distinct protein bands were visible, varying from $12\left(\mathrm{~S}_{12}\right)$ to 25 bands $\left(\mathrm{S}_{1}, \mathrm{~S}_{2}, \mathrm{~S}_{3}\right)$ according to the sampling stations (Fig. $2 \mathrm{~A}$ and Fig. S1 of Appendix). Among these, $53 \pm 11 \%(n=13)$ characterized protein groups with $50 \mathrm{kDa}<\mathrm{MW}<242 \mathrm{kDa}$, corresponding to high MW proteins. The low number of protein bands associated with the high MW that they presented suggest that the 1D extraction protocol here used may be was not enough efficient to dissociate some zooplankton protein complexes, which therefore remained combined with high MW. However, we distinguished 25 bands with similar MW that were common between the stations $S_{1}$ and $S_{13}$ of Toulon Bay, indicating same protein species in these stations. These proteins are presented with their respective band numbers and intensities (Fig. 2B and Fig. S1 of Appendix).

On the 2D-gels, the total number of zooplankton protein spots ranged from $16\left(\mathrm{~S}_{9}\right)$ to 98 spots $\left(\mathrm{S}_{3}\right)$. Among these, $97 \pm 3 \%(n=13)$ corresponded to small proteins with $13 \mathrm{kDa}<\mathrm{MW}<50 \mathrm{kDa}$, and pI between 4.1 and 6.7 (Fig. 3).
This proportion, greatly differing from that obtained for the 1Dgels, indicated a discrepancy between our 1-DE and 2-DE results. This suggests that the 1D and 2D extraction protocols may induce a different solubilisation of the zooplankton proteins that would lead to a better dissociation of protein complexes by the 2-DE extraction protocol. Thirteen spots with similar $\mathrm{MW} / \mathrm{pI}$ were common between the stations $S_{1}$ and $S_{13}$ of Toulon Bay. These proteins, named a, b, c, d, e, A, B, C, D, 1, 2, 3 and 4, are presented with their respective $\mathrm{MW} / \mathrm{pI}$ and intensities (Table 1 ). Of the 13 spots, those named a, d, e, A, B, C, D, 1 and 4 were putatively identified by comparison to sequences in the protein database at the NCBI (Table S2 of Appendix). Most of the protein spots (a, d, e, A, $C, D, 1$ ) were identified as actin (entire or fragments) (Table 2). Two spots were differently assigned, to tubulin (spot 4) and to calreticulin (spot B). Actin and tubulin are involved into cytoskeletal activities, whereas calreticulin is a protein chaperone.

\subsection{Zooplankton communities}

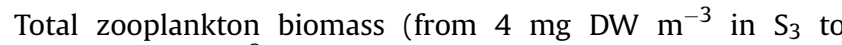
$396 \mathrm{mg}$ DW $\mathrm{m}^{-3}$ in $\mathrm{S}_{7}$ ), was slightly higher in LiB $\left(\right.$ mean $\left.=141 \mathrm{mg} \mathrm{DW} \mathrm{m}^{-3}\right)$ than in LaB $\left(\right.$ mean $=125 \mathrm{mg} \mathrm{DW} \mathrm{m}^{-3}$ ) (Table 3). However, total zooplankton abundance was twice as high in $\mathrm{LiB}\left(\right.$ mean $=32730$ ind $\left.\mathrm{m}^{-3}\right)$ than in $\mathrm{LaB}\left(\right.$ mean $\left.=16859 \mathrm{ind}^{-3}\right)$. Save for the Appendicularian Oikopleura spp., zooplankton biomass was principally due to Copepods, which also represented most of the total zooplankton abundance ( $71 \%$ on average). Copepod biomass and abundance were twice as high in $\mathrm{LiB}\left(15 \mathrm{mg} \mathrm{DW} \mathrm{m}^{-3}\right.$ and

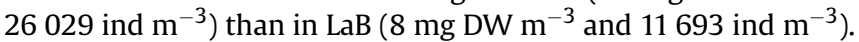

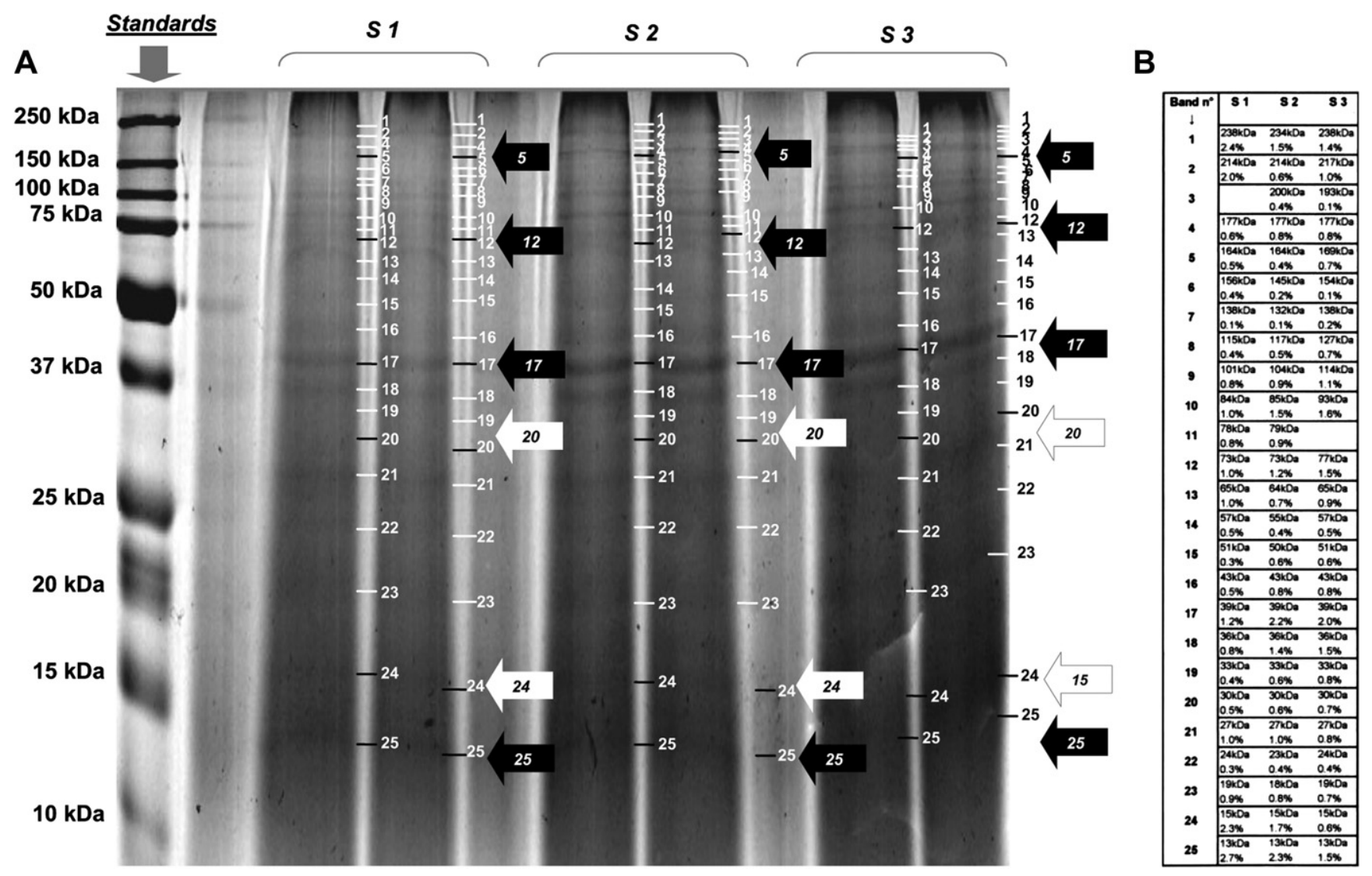

Fig. 2. A: 1D-polyacrylamide gel of total zooplankton proteins from the sampling stations $S_{1}, S_{2}, S_{3}$ of Toulon Bay. Protein bands present in most of the sampling stations are marked with white lines whereas black lines mark proteins showing significant correlations with trace metal concentrations ( $\mathrm{Cu}, \mathrm{Pb}$ and $\mathrm{Zn}$ ). Black and white arrows show protein bands respectively correlating negatively or positively with the trace metals. B: Molecular weight and relative intensity of each protein band detected. 

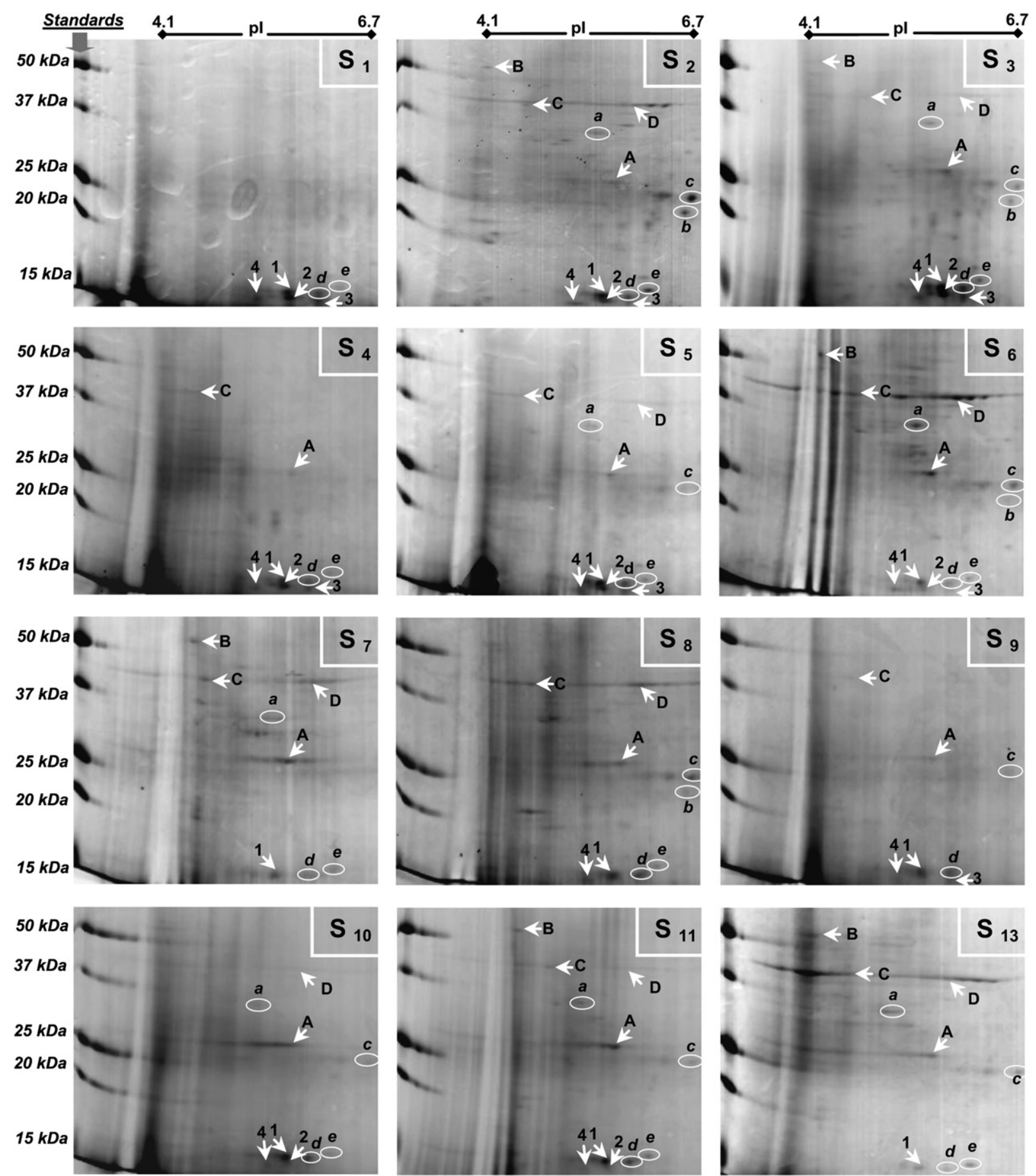

Fig. 3. 2D-polyacrylamide gels of total zooplankton proteins for the sampling stations $S_{1}-S_{13}$ of Toulon Bay. Protein spots a, b, c, d, e and f, are proteins showing no correlation with trace metal concentrations, but correlations $(p<0.05)$ and relations $(0.05<p<0.10)$ with biomasses of some zooplankton species, genera, or groups. Protein spots A, B, C and D, are proteins showing positive correlations $(p<0.05)$ with trace metal concentrations ( $\mathrm{Cu}, \mathrm{Pb}$ and $\mathrm{Zn})$, and correlations $(p<0.05)$ with biomasses of some zooplankton species, genera, or groups. Protein spots $1,2,3$ and 4 , are proteins showing negative correlations $(p<0.05)$ with trace metal concentrations $(\mathrm{Cu}, \mathrm{Pb}$ and $\mathrm{Zn})$, and correlations $(p<0.05)$ with biomasses of some zooplankton species, genera, or groups. ${ }^{*} 2 \mathrm{D}$-gel was not shown for $\mathrm{S}_{12}$, due to the incomplete data obtained in this station.

In LiB, Copepods were mainly composed of Cyclopoids (mean biomass $=8 \mathrm{mg} \mathrm{DW} \mathrm{m} \mathrm{m}^{-3}$ [48\% of Copepod biomass]; mean abundance $=13384$ ind $^{-3}$ [ $50 \%$ of Copepod abundance]), although Calanoids were also present (mean biomass $=6 \mathrm{mg} \mathrm{DW} \mathrm{m}^{-3}[37 \%$ of Copepod biomass]; mean abundance $=2282$ ind $\mathrm{m}^{-3}$ [ $9 \%$ of Copepod abundance]). Among the Cyclopoids in LiB, the species 0 . nana was clearly predominant in $\mathrm{S}_{11}$ and in $\mathrm{S}_{12}(80 \%$ of the Cyclopoid biomass and $74 \%$ of the Cyclopoid abundance in $S_{11} ; 76 \%$ of the Cyclopoid biomass and $74 \%$ of the Cyclopoid abundance in $\mathrm{S}_{12}$ ). This result was confirmed by the strong contributions of the Oithona genus to the whole zooplankton biomass in $\mathrm{S}_{11}(43 \%)$ and in $\mathrm{S}_{12}$ (36\%) (Fig. 4). The 0 . nana females were generally more present than the male ones, except in $S_{13}$ where equal proportions in biomass prevailed.

In LaB, although Cyclopoids were more numerous than Calanoids (mean abundances $=2429$ ind $\mathrm{m}^{-3}$ for Cyclopoids $v s$ 1216 ind $\mathrm{m}^{-3}$ for Calanoids, mean contributions to Copepod 
Table 1

Molecular weights (MW in $\mathrm{kDa}$ ), isoelectric points (pI) and intensities (in \%) of zooplankton protein spots detected on the $2 \mathrm{D}$-gels, for the sampling stations $\mathrm{S}_{1}-\mathrm{S}_{13}$ in Toulon Bay. MW, pI and intensities values were not shown for $\mathrm{S}_{12}$, due to the incomplete data obtained in this station.

\begin{tabular}{|c|c|c|c|c|c|c|c|c|c|c|c|c|c|}
\hline Spot $n^{\circ}$ & & $\mathrm{S}_{1}$ & $\mathrm{~S}_{2}$ & $\mathrm{~S}_{3}$ & $\mathrm{~S}_{4}$ & $\mathrm{~S}_{5}$ & $\mathrm{~S}_{6}$ & $S_{7}$ & $\mathrm{~S}_{8}$ & $\mathrm{~S}_{9}$ & $S_{10}$ & $\mathrm{~S}_{11}$ & $S_{13}$ \\
\hline $\bar{a}$ & $\begin{array}{l}\text { MW } 31.2 \\
\text { pI } 5.3\end{array}$ & - & 0.6 & 1.2 & - & 0.8 & 5.2 & 1.2 & - & - & 0.3 & 0.7 & 1.6 \\
\hline b & $\begin{array}{l}\text { MW } 20.1 \\
\text { pI } 6.6\end{array}$ & - & 5.7 & 1.7 & - & - & 0.1 & - & 0.3 & - & - & - & - \\
\hline c & $\begin{array}{l}\text { MW } 22.6 \\
\text { pI } 6.6\end{array}$ & - & 17.8 & 1.5 & - & 1.0 & 1.8 & - & 7.4 & 0.3 & 0.7 & 3.3 & 1.0 \\
\hline d & $\begin{array}{l}\text { MW } 14.2 \\
\text { pI } 6.0\end{array}$ & 4.5 & 0.5 & 4.3 & 1.5 & 10.0 & 1.0 & 1.3 & 7.8 & 1.7 & 3.2 & 3.0 & 0.1 \\
\hline e & $\begin{array}{l}\text { MW } 14.5 \\
\text { pI } 6.2\end{array}$ & 0.5 & 6.2 & 2.0 & 0.3 & 2.5 & 0.9 & 0.5 & 1.4 & - & 0.7 & 2.4 & 2.0 \\
\hline A & $\begin{array}{l}\text { MW } 25.0 \\
\text { pI } 5.6\end{array}$ & - & 0.5 & 3.8 & 0.3 & 3.7 & 5.9 & 9.6 & 8.8 & 1.9 & 5.9 & 6.8 & 2.9 \\
\hline B & $\begin{array}{l}\text { MW } 48.8 \\
\text { pI } 4.1\end{array}$ & - & 1.1 & 0.8 & - & - & 4.4 & 1.8 & - & - & 0.3 & 1.2 & 0.3 \\
\hline C & $\begin{array}{l}\text { MW } 38.2 \\
\text { pl } 4.4\end{array}$ & - & 0.3 & 0.2 & 0.6 & 0.1 & 1.9 & 1.7 & 1.3 & - & 0.8 & 1.1 & 0.9 \\
\hline D & $\begin{array}{l}\text { MW } 38.3 \\
\text { pI } 5.8\end{array}$ & - & 1.1 & 0.1 & - & 0.6 & 21.7 & 4.7 & 3.6 & - & 1.1 & 0.3 & 5.8 \\
\hline 1 & $\begin{array}{l}\text { MW } 14.2 \\
\text { pI } 5.6\end{array}$ & 14.9 & 19.6 & 16.3 & 6.6 & 17.7 & 3.3 & 4.2 & 24.5 & 12.2 & 9.4 & 13.2 & 0.8 \\
\hline 2 & $\begin{array}{l}\text { MW } 13.9 \\
\text { pI } 5.6\end{array}$ & 7.8 & 7.8 & 7.5 & 5.3 & 9.3 & 2.3 & - & - & - & 0.2 & 5.1 & - \\
\hline 3 & $\begin{array}{l}\text { MW } 13.7 \\
\text { pI } 6.0\end{array}$ & 6.8 & 1.5 & 2.8 & 1.1 & 2.4 & 0.2 & - & - & 0.1 & - & 0.7 & - \\
\hline 4 & $\begin{array}{l}\text { MW } 13.8 \\
\text { pI } 5.2\end{array}$ & 3.1 & 3.1 & 3.0 & 0.7 & 8.1 & 1.8 & - & 3.3 & 0.4 & 0.8 & 1.0 & - \\
\hline
\end{tabular}

abundance $=22 \%$ for Cyclopoids vs $8 \%$ for Calanoids), Copepod biomass resulted from Calanoids (mean biomasses $=4 \mathrm{mg} \mathrm{DW} \mathrm{m}^{-3}$ for Calanoids vs $1 \mathrm{mg} \mathrm{DW} \mathrm{m}^{-3}$ for Cyclopoids, mean contributions to Copepod biomass $=44 \%$ for Calanoids vs $24 \%$ for Cyclopoids). Regarding minority zooplankton groups, Mollusca larvae were greater contributors to the whole zooplankton biomass in LiB (mean contribution $=8 \%$ ) than in $\mathrm{LaB}$ (mean contribution $=3 \%$ ). In contrast, Cladocerans and Harpacticoids were less represented in $\mathrm{LiB}$ ( $8 \%$ and $1 \%$, respectively) than in $\mathrm{LaB}$ ( $16 \%$ and $10 \%$, respectively). The Shannon index of diversity indicated a drastic decrease in $\mathrm{LiB}$, from 3.62 bits ind $^{-1}$ in $\mathrm{S}_{10}$ (the nearest station to LaB) to 1.91 bits ind $^{-1}$ in $S_{13}$ (the station nearest to the port).

\subsection{Total dissolved trace metal concentrations}

Very low levels of total dissolved $\mathrm{Cd}$ concentrations were recorded in all stations of Toulon Bay (mean $=0.05 \pm 0.01 \mathrm{nM}$ ), without clear trend (Fig. 5). In contrast, clear decreasing gradients were observed for the other three trace metals, from the north to the south of $\mathrm{LiB}$ (i.e. from $\mathrm{S}_{13}$ to $\mathrm{S}_{9}$ ), and from the $\mathrm{LiB} / \mathrm{LaB}$ interface to the open sea (i.e. from $S_{7}$ to $S_{1}$ ). Except for $C d$, distributions of trace metals in Toulon Bay strongly correlated between them $(p<0.05)$, with $r$ values of $0.96(\mathrm{Zn} v s \mathrm{Cu}$ ), 0.80 ( $\mathrm{Pb}$ vs $\mathrm{Cu}$ ), and 0.79 ( $\mathrm{Pb}$ vs $\mathrm{Zn}$ ). In $\mathrm{LiB}$, minimal and maximal concentrations were respectively (expressed in $\mathrm{nM}$ ): $13.5 \pm 0.2$ and $23.8 \pm 0.5$ for $\mathrm{Cu}, 0.73 \pm 0.02$ and $1.24 \pm 0.02$ for $\mathrm{Pb}$, and $27.8 \pm 1.3$ and $58.7 \pm 2.2$ for $\mathrm{Zn}$. These levels were clearly lower in LaB, reaching: $2.2 \pm 0.4$ and $15.6 \pm 0.2$ for $\mathrm{Cu}$, $0.19 \pm 0.02$ and $0.78 \pm 0.02$ for $\mathrm{Pb}$, and $9.0 \pm 0.1$ and $38.8 \pm 0.7$ for Zn.

\subsection{Relationships between zooplankton and total dissolved trace metals}

The changes of some zooplankton species, genera or group (expressed in \% of the total biomass) were closely related to those of total dissolved trace metals (Table 4). Biomasses of Euterpina acutifrons, Microsetella norvegica, Acartia spp. and Evadne nordmanni, members of a zooplankton group that we defined as zooplankton group 1, composed of Cladocerans, Calanoids, Harpacticoids and Cirripede nauplii, negatively correlated $(p<0.05)$ with total dissolved $\mathrm{Cu}, \mathrm{Pb}$ and $\mathrm{Zn}$ concentrations. By contrast, biomasses of Mollusca larvae and $O$. nana, members of a zooplankton group that we defined as zooplankton group 2, composed of Mollusca larvae and Cyclopoids, positively correlated $(p<0.05)$ with total dissolved

Table 2

LC-MS/MS identification of zooplankton protein spots present on the 2D-gels.

\begin{tabular}{|c|c|c|c|c|c|c|}
\hline \multirow[t]{2}{*}{ Spot $n^{\circ}$} & \multirow[t]{2}{*}{ Number of peptides } & \multicolumn{2}{|c|}{ MW (kDa)/pI } & \multirow[t]{2}{*}{ Putative protein identification } & \multirow[t]{2}{*}{ Species name/NCBI accession number } & \multirow[t]{2}{*}{ Annotated biological function } \\
\hline & & Exp. & Theo. & & & \\
\hline $\mathrm{a}$ & 4 & $31.2 / 5.3$ & $41.8 / 5.5$ & Actin & Aplysia californica P17304 & Cytoskeleton structure/function (42.04.03) \\
\hline d & 18 & $14.2 / 6.0$ & $41.8 / 5.5$ & Actin & Artemia sp. P18601 & Cytoskeleton structure/function (42.04.03) \\
\hline e & 9 & $14.5 / 6.2$ & $41.7 / 5.7$ & Actin & Mytilus galloprovincialis Q9Y0D6 & Cytoskeleton structure/function (42.04.03) \\
\hline A & 23 & $25.0 / 5.6$ & $41.8 / 5.4$ & Actin & Strongylocentrotus purpuratus P18499 & Cytoskeleton structure/function (42.04.03) \\
\hline B & 4 & $48.8 / 4.1$ & $47.3 / 4.7$ & Calreticulin & Amblyomma rotundatum $\mathrm{Q} 64 \mathrm{~K} 96$ & Chaperone (14.01) \\
\hline C & 11 & $38.2 / 4.4$ & $41.8 / 5.5$ & Actin & Spodoptera littoralis Q11212 (fragment) & Cytoskeleton structure/function (42.04.03) \\
\hline $\mathrm{D}$ & 27 & $38.3 / 5.8$ & $41.7 / 5.7$ & Actin & Mytilus galloprovincialis Q9Y0D6 & Cytoskeleton structure/function (42.04.03) \\
\hline 1 & 12 & $14.2 / 5.6$ & $42.0 / 5.4$ & Actin & Molgula oculata P53467 & Cytoskeleton structure/function (42.04.03) \\
\hline 4 & 6 & $13.8 / 5.2$ & $49.6 / 4.9$ & Tubulin & Danio rerio Q6PE34 & Cytoskeleton structure/function (42.04.05) \\
\hline
\end{tabular}


Table 3

Biomasses (in $\mathrm{mg} \mathrm{DW} \mathrm{m}^{-3}$ ) of zooplankton groups and species, and zooplankton diversity expressed as Shannon index $\left(\mathrm{H}^{\prime}\right.$ in bits ind $\left.{ }^{-1}\right)$, for the sampling stations $\mathrm{S}_{1}-\mathrm{S}_{13}$ in Toulon Bay.

\begin{tabular}{|c|c|c|c|c|c|c|c|c|c|c|c|c|c|}
\hline Zooplankton biomass & $\mathrm{S}_{1}$ & $\mathrm{~S}_{2}$ & $\mathrm{~S}_{3}$ & $\mathrm{~S}_{4}$ & $\mathrm{~S}_{5}$ & $\mathrm{~S}_{6}$ & $\mathrm{~S}_{7}$ & $\mathrm{~S}_{8}$ & $\mathrm{~S}_{9}$ & $\mathrm{~S}_{10}$ & $\mathrm{~S}_{11}$ & $\mathrm{~S}_{12}$ & $\mathrm{~S}_{13}$ \\
\hline Polydora spp. & - & - & - & - & - & - & 0.61 & - & - & - & - & - & - \\
\hline Parasagitta spp. & - & - & - & - & - & - & 12.63 & - & - & - & - & - & - \\
\hline Gasteropoda larvae & 0.24 & - & - & - & 0.19 & - & 1.29 & 0.38 & 0.32 & 1.39 & 2.13 & 1.17 & 0.43 \\
\hline Bivalvia larvae & - & 0.02 & - & - & - & 0.02 & 0.06 & - & - & 0.18 & 0.18 & 0.08 & - \\
\hline Evadne nordmanni & - & - & - & 0.58 & 1.28 & - & - & - & - & - & - & - & - \\
\hline Evadne spinifera & - & - & - & - & - & 1.16 & 1.46 & - & 3.30 & - & - & - & - \\
\hline Penilia avirostris & 0.60 & 1.51 & 0.41 & 0.43 & - & - & - & 0.48 & - & 2.61 & 1.95 & 1.46 & - \\
\hline Cirripedia nauplii & - & - & 0.70 & 1.44 & - & - & 2.74 & 3.25 & - & - & 1.64 & - & - \\
\hline Calanoida copepodites & 0.84 & 4.81 & - & 2.36 & 0.26 & 0.48 & 0.90 & 0.27 & 2.70 & 2.17 & 4.05 & 2.43 & 2.38 \\
\hline Acartia spp. & 2.47 & 3.08 & - & 1.74 & - & - & - & - & 3.31 & - & - & - & - \\
\hline Acartia clausi & - & 3.08 & - & - & - & - & 2.20 & - & - & - & - & - & - \\
\hline Clausocalanus parapergens & - & - & - & - & - & - & 0.86 & - & - & - & - & - & - \\
\hline Clausocalanus pergens & - & 0.61 & - & 1.36 & - & 0.69 & - & 0.77 & 2.60 & 3.48 & - & 1.17 & - \\
\hline Paracalanus spp. & - & - & - & - & - & - & - & - & - & - & 3.12 & 2.92 & - \\
\hline Paracalanus parvus & - & 0.61 & - & - & - & - & 1.73 & - & - & 0.70 & - & - & - \\
\hline Corycaeus latus & - & - & - & - & 0.54 & - & - & - & - & 0.50 & - & 0.42 & - \\
\hline Cyclopoida copepodites & 0.41 & 1.76 & 0.34 & 0.52 & 0.39 & 0.24 & 0.59 & 0.26 & 0.78 & 1.91 & 2.20 & 1.25 & 2.73 \\
\hline Oithona nana copepodites & - & 0.21 & - & - & - & - & 0.07 & - & 0.22 & 1.07 & 3.87 & 2.26 & - \\
\hline Oithona nana females & - & - & - & - & - & 0.13 & 0.17 & - & - & 0.55 & 6.10 & 3.21 & 0.51 \\
\hline Oithona nana males & - & - & - & - & - & - & - & - & - & 0.27 & 1.22 & 0.57 & 0.51 \\
\hline Oithona setigera & - & - & - & 0.18 & - & - & - & - & - & - & - & - & - \\
\hline Oithona similis & 0.16 & 1.20 & 1.52 & 0.56 & 0.25 & 0.11 & 0.57 & 0.51 & 0.43 & 0.58 & 0.52 & 0.19 & - \\
\hline Harpacticoida spp. & - & & 0.05 & 0.05 & 0.34 & - & - & - & - & - & - & - & 0.06 \\
\hline Euterpina acutifrons & 0.08 & 0.10 & 0.21 & 0.22 & 0.24 & 0.16 & 0.21 & - & 0.10 & 0.22 & 0.06 & - & - \\
\hline Microsetella rosea & - & 0.74 & - & 0.28 & - & - & - & - & - & - & - & - & - \\
\hline Microsetella norvegica & 0.39 & 2.70 & 0.27 & 0.55 & 0.62 & - & 0.35 & - & - & - & 0.32 & - & - \\
\hline Nauplii of Copepoda & 1.28 & 2.17 & 0.32 & 1.47 & 0.74 & 1.52 & 1.42 & 0.72 & 1.80 & 0.99 & 1.86 & 1.88 & 2.41 \\
\hline Parasagitta spp. & - & - & - & - & - & - & 12.63 & - & - & - & - & - & - \\
\hline Oikopleura spp. & 68.54 & 21.50 & - & 169.01 & 107.69 & 73.25 & 367.92 & 27.22 & 184.63 & 197.64 & 221.05 & 41.49 & 30.51 \\
\hline Shannon index $\left(\mathrm{H}^{\prime}\right)$ & 2.65 & 2.75 & 2.28 & 2.09 & 3.08 & 2.31 & 3.36 & 2.72 & 2.64 & 3.62 & 3.29 & 3.07 & 1.91 \\
\hline Total biomass & 75.02 & 44.10 & 3.81 & 180.75 & 112.54 & 77.76 & 395.78 & 33.85 & 200.20 & 214.25 & 250.27 & 60.50 & 39.53 \\
\hline
\end{tabular}

$\mathrm{Cu}, \mathrm{Pb}$ and $\mathrm{Zn}$ concentrations. Finally, total dissolved $\mathrm{Cd}$ concentrations showed some correlations $(p<0.05)$ with zooplankton; these were positive with Cyclopoida copepodites, Oithona genus, Cyclopoids and Copepods, and negative with Oikopleura spp.

\subsection{Relationships between protein expression and zooplankton}

Among the protein bands detected, 17 presented positive correlations $(p<0.05)$ with biomasses (in \%) of zooplankton species, genera, or groups (Table 5). Two groups of positive correlations were distinguished: correlations between bands $\mathrm{n}^{\circ} 1$ (237 kDa), 4 (176 kDa), 6 (151 kDa), 7 (135 kDa), 11 (77 kDa), 12 (72 kDa), 14 (58 kDa), 15 (51 kDa), 16 (43 kDa), 17 (40 kDa), 18 (36 kDa), $19(34 \mathrm{kDa}), 23(20 \mathrm{kDa})$ and $25(12 \mathrm{kDa})$ and members of zooplankton group 1 (in grey in Table 5), and then, correlations between bands $n^{\circ} 8$ (118 kDa), $10(85 \mathrm{kDa})$ and $24(15 \mathrm{kDa})$ and members of zooplankton group 2 (in black in Table 5). However, correlations with the highest MW protein groups have to be cautiously regarded, to take into account the potential incomplete dissociation of protein complexes due to the 1D extraction protocol.

Among the spots detected, 13 presented positive correlations $(p<0.05)$ or relations $(0.05<p<0.10)$ with biomasses (in \%) of zooplankton species, genera, or groups. Positive correlations or relations were found between spots $1,2,3,4$, b and some zooplankton members of group 1 (Cladocerans, Harpacticoids) (in grey in Table 6), whereas positive correlations or relations were obtained between spots B, C, D, a, c, e and some zooplankton members of group 2 (Mollusca larvae, Cyclopoids) (in black in Table 6). In addition, spots A and d negatively correlated $(p<0.05)$ respectively with biomass of a zooplankton member of group 1 (Acartia spp.: $r=-0.80$ ) and with biomass of a zooplankton member of group 2 (0. nana: $r=-0.60$ ).
3.6. Relationships between zooplankton protein expression and total dissolved trace metals

Protein bands $\mathrm{n}^{\circ} 20(30 \mathrm{kDa})$ and $24(15 \mathrm{kDa})$ showed positive correlations $(p<0.05)$ with the total dissolved $\mathrm{Cu}, \mathrm{Pb}$ and $\mathrm{Zn}$ concentrations in seawater (Fig. 6).

No correlation or relation was found between spots a, b, c, d, e, f and $\mathrm{Cu}, \mathrm{Pb}, \mathrm{Zn}$. By contrast, spots $\mathrm{A}, \mathrm{C}$ and $\mathrm{D}$ assigned to actin, positively correlated $(p<0.05)$ or related $(0.05<p<0.10)$ with these trace metals, whereas spot $\mathrm{B}$, assigned to calreticulin, positively related $(0.05<p<0.10)$ with Zn (Fig. 6). However, spots 1, 2, 3, 4, identified as actin for 1 , and as tubulin for 4 , showed negative correlations $(p<0.05)$ with $\mathrm{Cu}$ and $\mathrm{Zn}$ (spot $1: r=-0.60$ with $\mathrm{Cu}$ and -0.59 with $\mathrm{Zn}$; spot $2: r=-0.84$ with $\mathrm{Cu}$ and -0.80 with $\mathrm{Zn}$; spot 3: $r=-0.85$ with $\mathrm{Cu}$ and -0.85 with $\mathrm{Zn}$; spot $4: r=-0.70$ with $\mathrm{Cu}$ and -0.65 with $\mathrm{Zn})$. Spots $1,2,3$ negatively related $(0.05<p<0.10)$ with $\mathrm{Pb}$ (spot 1: $r=-0.55$; spot 2: $r=-0.53$; spot 3: $r=-0.55$ ).

\section{Discussion}

\subsection{Zooplankton proteins}

Unexpected different patterns in protein distribution were observed according to the method used to extract and separate proteins. Zooplankton extracts submitted to 1-DE contained similar proportions of small (13 $\mathrm{kDa}<\mathrm{MW}<50 \mathrm{kDa}$ ) and large proteins (50 kDa $<$ MW $<242 \mathrm{kDa}$ ). This was not observed for the zooplankton extracts analysed by 2-DE, which contained almost exclusively small proteins ( $13 \mathrm{kDa}<\mathrm{MW}<50 \mathrm{kDa}$ ). This discrepancy could result from the different extraction protocols used: 1-DE extraction used SDS, 2-mercaptoethanol and urea, whereas 2-DE extraction needed urea, thiourea, CHAPS, Triton X-100 and DTT. Similarly to us, Jones et al. (2004) observed a discrepancy between 

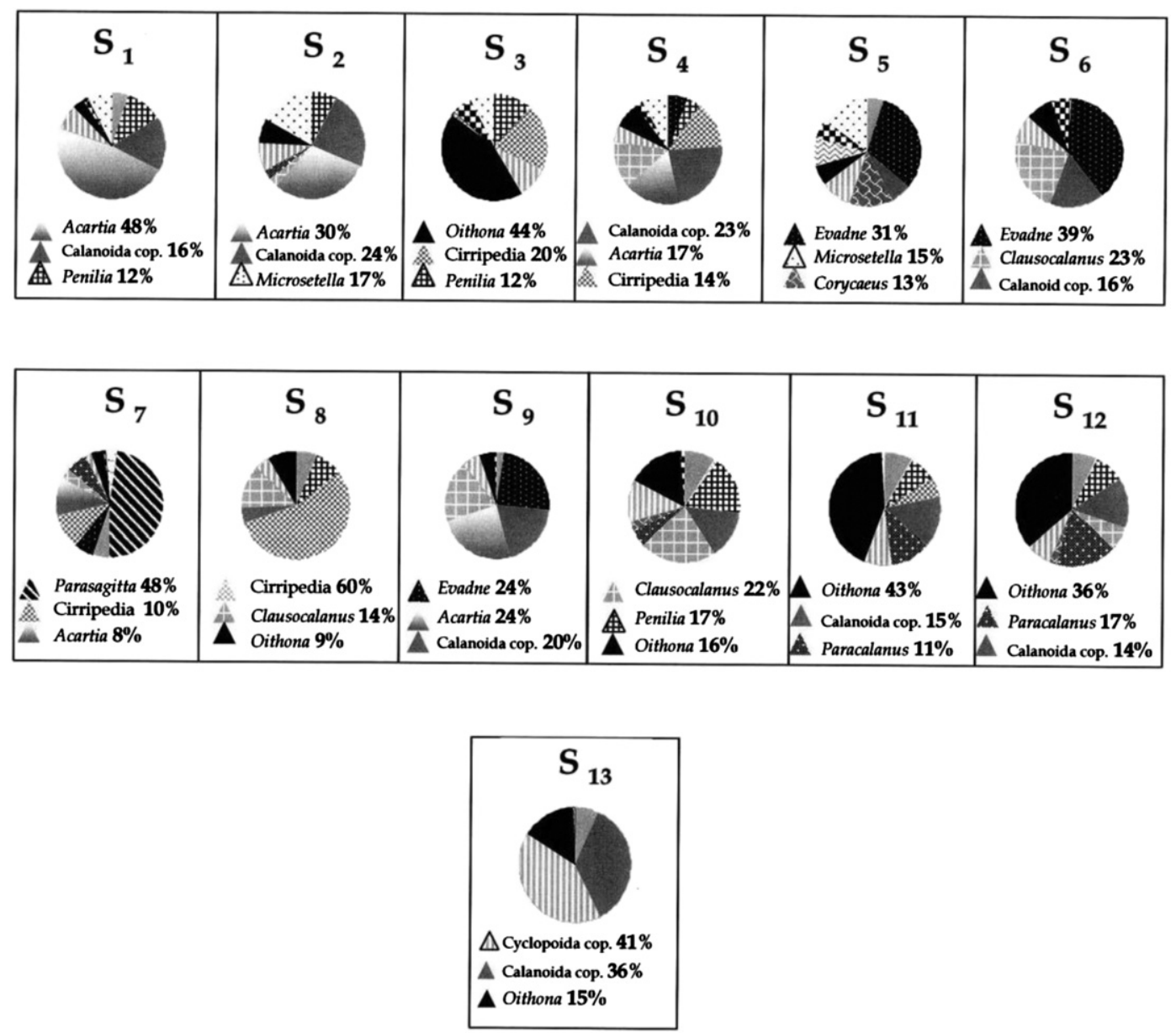

Fig. 4. Contributions (in \%) of zooplankton genera and groups to zooplankton biomass (without Oikopleura spp. and Nauplii of Copepoda) for the sampling stations $\mathrm{S}_{1}-\mathrm{S}_{13}$ in Toulon Bay. For each station, the three predominant groups are indicated with their respective contributions to biomass.

1-DE and 2-DE results about the protein characterisation in aquatic samples. These authors interpret this result by the different potential to solubilize proteins of the solutions used in SDS-PAGE compared with 2D-PAGE. They induce a different solvation of proteins and non-proteinaceous contaminants, and thus lead to visualisation of different subsets of compounds on SDS-PAGE and 2D-PAGE. According to Jones et al. (2004), both methods would provide different informations and thus, could be used together as a tool for protein characterization: 1-DE to provide a sample-specific fingerprint, and 2-DE to characterize individual protein molecules. Here, 2-DE extraction was completed by freezing-thawing cycles and sonication, which enhanced efficiency of the protein extraction. As a result, membrane proteins could be better extracted, involving more numerous small proteins on 2D-gels, whereas protein groups with high MW on SDS-polyacrylamide gels could result from membrane protein complexes combining several proteins (Daley, 2008), more difficult to dissociate by the 1-DE extraction protocol.

\subsection{Zooplankton in Toulon Bay}

Previous annual cycles taking place in Toulon Bay showed peak in late spring-early summer (Jamet et al., 2005), suggesting that this period was favourable to a study about zooplankton. High zooplankton biomasses are classically recorded during spring in most regions of the western Mediterranean (Gaudy et al., 2003), where zooplankton peak twice: (i) in early spring, in response to the late winter phytoplankton bloom which follows the vertical mixing of seawater allowing to cold, dense and nutrient-rich waters reach the surface, (ii) in late spring, as in the present study, following phytoplankton growth which results from intermittent fertilization pulses associated with seasonal hydrographic perturbations (Fernandez de Puelles et al., 2007).

Zooplankton biomass and abundance in Toulon Bay (mean $=130 \mathrm{mg} \mathrm{DW} \mathrm{m}^{-3}$ and 21742 ind $\mathrm{m}^{-3}$, respectively) remained very high in comparison with those reported, at this period, from other mediterranean study sites (Fernandez de Puelles et al., 2007; Gaudy et al., 2003; Riandey et al., 2005; Yilmaz and Besiktepe, 2010). However, they are less than those observed in specific ecosystems, such as the Izmit Bay (NE Marmara Sea) where biomass reached up to $1400 \mathrm{mg} \mathrm{DW} \mathrm{m}^{-3}$ in March 2002 (Isinibilir et al., 2008). The closed and shallow Izmit Bay has been affected by anthropogenic influences during the last decade, which increased its nutrient and pollutant inputs. These disturbances have modified the zooplankton diversity in this ecosystem, as indicated by the low Shannon Index $\mathrm{H}^{\prime}$ there recorded (Isinibilir et al., 2008). We reported similar results, with a drop in $\mathrm{H}^{\prime}$ in the sampling stations that were closer to the port (minimal $\mathrm{H}^{\prime}$ in $\mathrm{S}_{13}$ ).

On average, the total zooplankton abundance was twice as high in $\mathrm{LiB}$ than in LaB. These results are similar to those that we have previously reported (Jamet et al., 2001, 2005). The anthropogenic inputs into $\mathrm{LiB}$, related to its semi-closed configuration, induce a greater eutrophication and a higher primary productivity, previously measured in this ecosystem (Jamet et al., 2001, 2005). By comparing zooplankton structures in $\mathrm{LiB}$ and $\mathrm{LaB}$, different proportions of Cyclopoids and Calanoids have been found among Copepods 

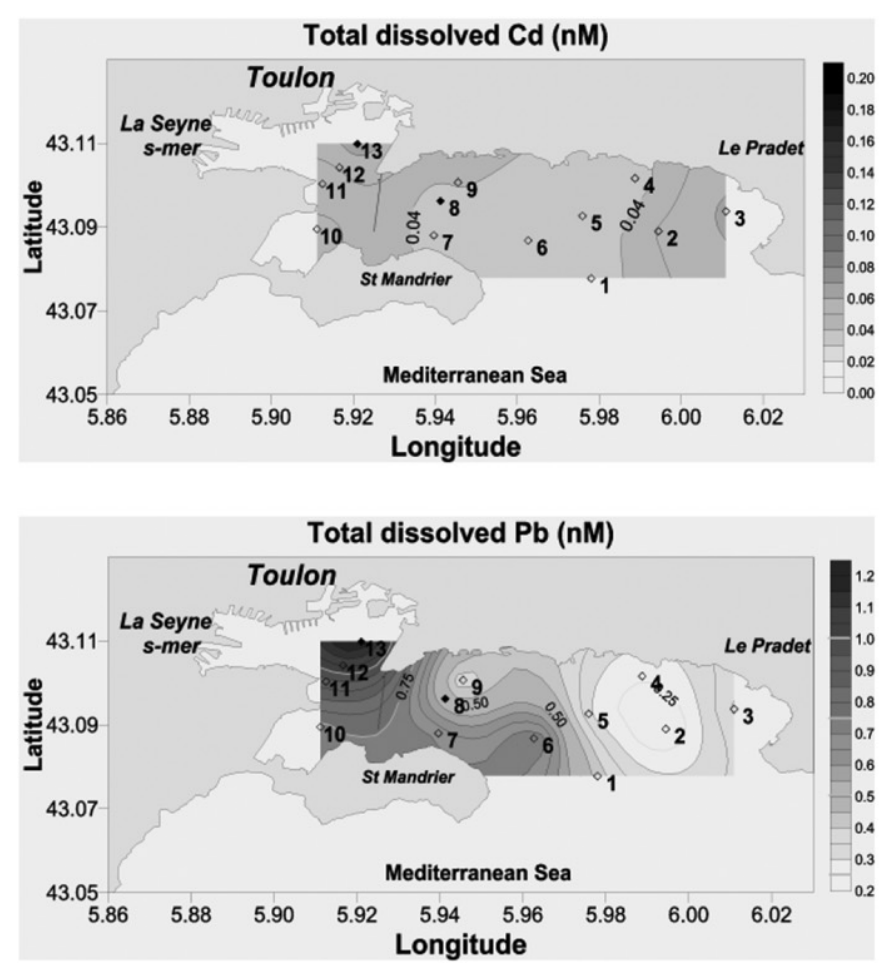
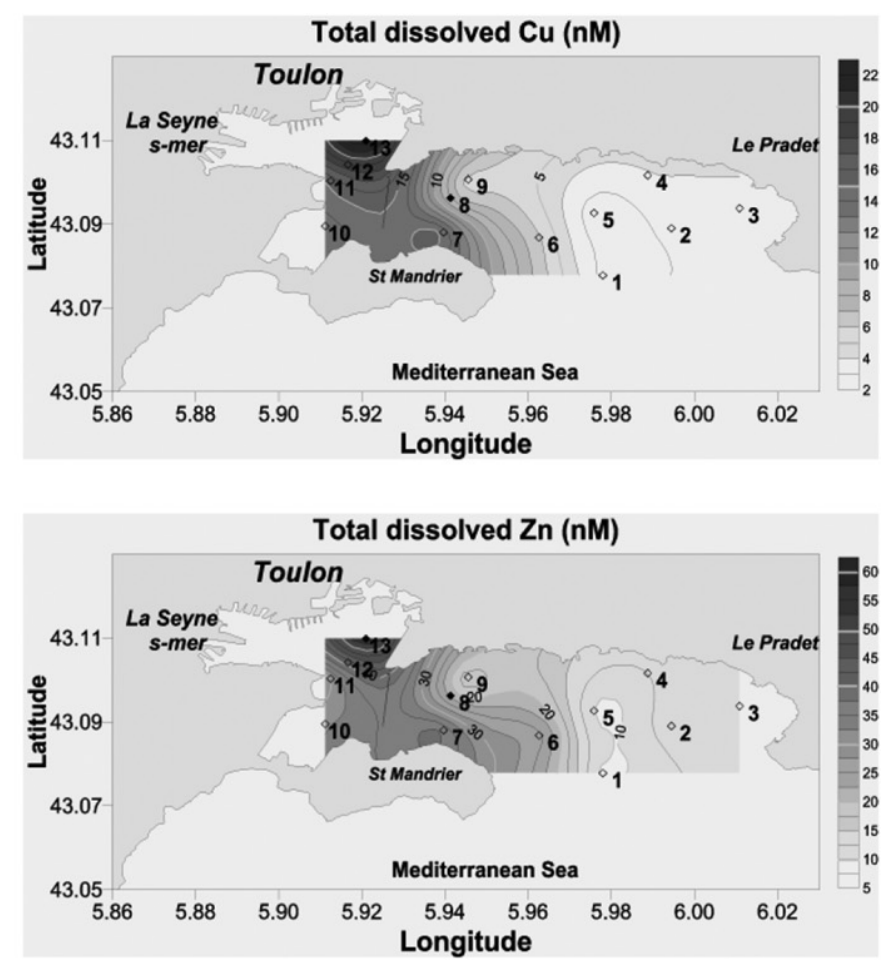

Fig. 5. Total dissolved trace metal concentrations ( $\mathrm{Cd}, \mathrm{Cu}, \mathrm{Pb}$ and $\mathrm{Zn}$ ) for sampling stations $\mathrm{S}_{1}-\mathrm{S}_{13}$ in Toulon Bay. (For logistic reasons, sampling for total dissolved trace metal analysis was not carried out in $\mathrm{S}_{12}$.)

which always constituted the majority of zooplankton. Many other mediterranean studies also report Copepods to be the most abundant zooplankton taxon (Fernandez de Puelles et al., 2007; Gaudy et al., 2003; Riandey et al., 2005; Yilmaz and Besiktepe, 2010). In LiB, Cyclopoids made up most of a small-sized Copepod population predominated by 0 . nana (in $S_{11}$ and $S_{12}$ ), with females of this species more abundant than males. This latter result supports previous studies in Toulon Bay where the sex ratio of $O$. nana was clearly in favour of females in LiB (Richard and Jamet, 2001).

In LaB, far away from the port and open to the sea, Calanoids were main contributors to Copepod biomass, although Cyclopoids were more numerous. Many studies have mentioned that the Calanoid assemblage Paracalanus/Clausocalanus is generally the more abundant population in the Mediterranean, followed by the Cyclopoids Oithona, Oncaea, or Corycaeus (Fernandez de Puelles et al., 2007; Gaudy et al., 2003; Riandey et al., 2005). This was not observed in Toulon Bay, but the predominant Calanoid biomass measured in LaB in comparison with LiB, could show evidence that zooplankton structure of $\mathrm{LaB}$ was closer to other Mediterranean areas than LiB.

\subsection{Trace metals in Toulon Bay}

With the exception of Cd present at very low levels, the significant and strong correlations between the metals studied suggest its similar sources and behaviours. Values measured in the $S_{1}$ station of LaB were comparable to levels already reported for the western Mediterranean Sea (Morley et al., 1997). In contrast, higher values recorded in the north of LiB reflect significant contamination, due to numerous anthropogenic activities and low seawater renewal. Understanding the metal toxicity to marine organisms requires knowledge of the bioavailability of metals, which is linked to speciation. Some chemical forms, such as the free hydrated ion metal, are more easily assimilated by biota (Hirose, 2007). Determination of metal speciation needs specific analytical tools and mathematical calculations using speciation codes (MINEQL, FITEQL, CHESS) (Herbelin and Westall, 1999; Van der Lee and De Windt, 2000; Westall et al., 1976). It is well known that, in aquatic systems, the DOM controls the metal speciation (Bruland and Lohan, 2004). We recently characterized the interactions between $\mathrm{Cu}^{2+}$ and marine DOM from Toulon Bay (Louis et al., 2009b). From the calculated DOM binding parameters, the $\mathrm{Cu}$ speciation and the concentration of free $\mathrm{Cu}^{2+}$ in the natural environment have been estimated. These parameters have been recently used to evaluate the effect of ocean acidification on the DOM control of metal speciation in seawater (Millero et al., 2010). Taking into account these data, free $\mathrm{Cu}^{2+}$ concentrations were calculated at each sampling station of Toulon Bay using the MINEQL program. These ranged from 0.8 to $6.5 \times 10^{-11} \mathrm{M}$ in LaB, and 5.3 to $12.5 \times 10^{-11} \mathrm{M}$ in LiB. Except in some stations of $\operatorname{LaB}\left(\mathrm{S}_{1}, \mathrm{~S}_{2}\right.$ and $\left.\mathrm{S}_{5}\right)$, all of the calculated values of free $\mathrm{Cu}^{2+}$ exceeded the defined toxicity limits for marine zooplankton (Sunda et al., 1987). Metal contamination could therefore be an important disturbance for these microorganisms in Toulon Bay.

\subsection{Relationships between zooplankton and trace metals}

The development of $O$. nana in LiB, suggests that this species could benefit from the primary productivity there measured (Jamet et al., 2001, 2005), but also that it could tolerate the level of contamination in this ecosystem. The large number of positive correlations between $\mathrm{O}$. nana and the concentrations of $\mathrm{Cu}, \mathrm{Pb}, \mathrm{Zn}$ could confirm this latter possibility, especially regarding females of this species, which were predominant in LiB. In contrast, Calanoids, Harpacticoids and Cladocerans, main contributors to Copepod biomass in LaB, showed many negative correlations between their representative species Acartia spp., E. acutifrons, Microsetella rosea, $M$. norvegica, E. nordmanni and concentrations of $\mathrm{Cu}, \mathrm{Pb}$ and $\mathrm{Zn}$. These observations suggest that $O$. nana and the species $E$. acutifrons, $M$. rosea and $M$. norvegica could oppositely respond towards 
Table 4

Positive and negative correlations $(p<0.05)$ between biomasses of zooplankton species, genera, or groups from sampling stations $S_{1}$ to $S_{13}$ in Toulon Bay and tota dissolved trace metal concentrations ( $\mathrm{Cd}, \mathrm{Cu}, \mathrm{Pb}$ and $\mathrm{Zn})$. Zooplankton group 1 is composed of Cladocerans, Calanoids, Harpacticoids and Cirripede nauplii. Zooplankton group 2 is comprised of Mollusca larvae and Cyclopoids.

\begin{tabular}{|c|c|c|}
\hline Metal & \multicolumn{2}{|c|}{ (+) Correlations (with zooplankton group 2) } \\
\hline $\mathrm{Cd}$ & & $\begin{array}{l}\text { Cyclopoida copepodites }(r=0.74) \\
\text { Oithona genus }(r=0.66) \\
\text { Cyclopoids }(r=0.64) \\
\text { Copepods }(r=0.63)\end{array}$ \\
\hline $\mathrm{Cu}$ & & $\begin{array}{l}\text { Gasteropoda larvae }(r=0.62) \\
\text { Mollusca larvae }(r=0.61) \\
\text { Oithona nana females }(r=0.79) \\
\text { Oithona nana males }(r=0.66) \\
\text { Oithona nana }(r=0.62)\end{array}$ \\
\hline $\mathrm{Pb}$ & $\Leftrightarrow$ & $\begin{array}{l}\text { Gasteropoda larvae }(r=0.63) \\
\text { Mollusca larvae }(r=0.62) \\
\text { Oithona nana females }(r=0.88) \\
\text { Oithona nana males }(r=0.72) \\
\text { Oithona nana }(r=0.59)\end{array}$ \\
\hline Zn & 8 & $\begin{array}{l}\text { Gasteropoda larvae }(r=0.65) \\
\text { Mollusca larvae }(r=0.67) \\
\text { Oithona nana females }(r=0.82) \\
\text { Oithona nana }(r=0.73)\end{array}$ \\
\hline \multicolumn{3}{|c|}{ (-) Correlations (with zooplankton group 1) } \\
\hline $\mathrm{Cd}$ & & Oikopleura spp. $(r=-0.69)$ \\
\hline $\mathrm{Cu}$ & & $\begin{array}{l}\text { Euterpina acutifrons }(r=-0.69) \\
\text { Microsetella norvegica }(r=-0.70) \\
\text { Microsetella genus }(r=-0.70) \\
\text { Harpacticoids }(r=-0.67)\end{array}$ \\
\hline $\mathrm{Pb}$ & 7 & $\begin{array}{l}\text { Acartia spp. }(r=-0.65) \\
\text { Acartia genus }(r=-0.62) \\
\text { Euterpina acutifrons }(r=-0.58) \\
\text { Microsetella rosea }(r=-0.65) \\
\text { Microsetella norvegica }(r=-0.62) \\
\text { Microsetella genus }(r=-0.64)\end{array}$ \\
\hline $\mathrm{Zn}$ & $\pi *$ & $\begin{array}{l}\text { Evadne nordmanni }(r=-0.59) \\
\text { Euterpina acutifrons }(r=-0.67) \\
\text { Microsetella norvegica }(r=-0.68) \\
\text { Microsetella genus }(r=-0.67) \\
\text { Harpacticoids }(r=-0.60)\end{array}$ \\
\hline
\end{tabular}

metal stress. At the time of the sampling, these Copepods probably have been exposed to environmental stresses other than trace metals. These potential stresses have not been evaluated in the present study, as a result, we cannot predict their impact on zooplankton communities. However, a nycthemeral study carried out during $27 \mathrm{~h}$ on September 2007 in LiB and LaB, reported no marked changes in salinity, and only minor changes in seawater temperatures $\left(0.5^{\circ} \mathrm{C}\right.$ at the most), whatever the seawater depth studied (Rossi, 2008). Our sampling has taken place in similar climatic conditions, consequently salinity and temperature stresses can be minimized, whereas the possibility of other stresses, especially contaminant, cannot be ruled out.

\subsection{Relationships between zooplankton proteins and trace metals}

Of the zooplankton proteins isolated by 2-DE, several were sequenced by LC-MS/MS, mainly indicating the presence of
Table 5

Positive correlations $(p<0.05)$ between changes in the intensities of zooplankton protein bands detected on the 1D-gels, and biomasses of zooplankton species, genera, or groups from sampling stations $S_{1}$ to $S_{13}$ in Toulon Bay. In grey, protein bands positively correlating with some members of zooplankton group 1 (Cladocerans, Calanoids, Harpacticoids and Cirripede nauplii). In black, protein bands positively correlating with some members of zooplankton group 2 (Mollusca larvae and Cyclopoids).

\begin{tabular}{|c|c|c|}
\hline Prote & ein band $n^{\circ}$ & Correlations with 4zooplankton \\
\hline 1 & $(237 k D a)$ & $\begin{array}{l}\text { Evadne nordmanni }(r=0.64) \\
\text { Harpacticoida spp. }(r=0.56) \\
\text { Harpacticoids }(r=0.62)\end{array}$ \\
\hline 4 & $(176 \mathrm{kDa})$ & $\begin{array}{l}\text { Euterpina acutifrons }(r=0.62) \\
\text { Microsetella norvegica }(r=0.59) \\
\text { Microsetella genus }(r=0.59) \\
\text { Harpacticoids }(r=0.64)\end{array}$ \\
\hline 6 & $(151 k D a)$ & Acartia spp. $(r=0.61)$ \\
\hline 7 & $(135 \mathrm{kDa})$ & $\begin{array}{l}\text { Evadne nordmanni }(r=0.65) \\
\text { Harpacticoida spp. }(r=0.79)\end{array}$ \\
\hline 8 & $(118 \mathrm{kDa})$ & $\begin{array}{l}\text { Bivalvia larvae }(r=0.62) \\
\text { Cyclopoida copepodites }(r=0.69) \\
\text { Oithona nana copepodites }(r=0.61) \\
\text { Oithona nana males }(r=0.55) \\
\text { Oithona nana }(r=0.61) \\
\text { Oithona genus }(r=0.58) \\
\text { Cyclopoids }(r=0.57) \\
\text { Copepods }(r=0.60)\end{array}$ \\
\hline 10 & $(85 \mathrm{kDa})$ & Copepods $(r=0.64)$ \\
\hline 11 & $(77 \mathrm{kDa})$ & Evadne nordmanni $(r=0.65)$ \\
\hline 12 & $(72 k D a)$ & $\begin{array}{l}\text { Evadne nordmanni }(r=0.63) \\
\text { Euterpina acutifrons }(r=0.66) \\
\text { Microsetella norvegica }(r=0.69) \\
\text { Microsetella genus }(r=0.68) \\
\text { Harpacticoids }(r=0.61)\end{array}$ \\
\hline 14 & $(58 \mathrm{kDa})$ & $\begin{array}{l}\text { Evadne nordmanni }(r=0.64) \\
\text { Harpacticoida spp. }(r=0.76) \\
\text { Microsetella norvegica }(r=0.66) \\
\text { Microsetella genus }(r=0.65) \\
\text { Harpacticoids }(r=0.82)\end{array}$ \\
\hline 15 & $(51 \mathrm{kDa})$ & $\begin{array}{l}\text { Evadne nordmanni }(r=0.62) \\
\text { Harpacticoida spp. }(r=0.60)\end{array}$ \\
\hline 16 & $(43 k D a)$ & Evadne nordmanni $(r=0.63)$ \\
\hline 17 & $(40 \mathrm{kDa})$ & $\begin{array}{l}\text { Evadne nordmanni }(r=0.64) \\
\text { Harpacticoida spp. }(r=0.72)\end{array}$ \\
\hline 18 & $(36 k D a)$ & $\begin{array}{l}\text { Evadne nordmanni }(r=0.63) \\
\text { Harpacticoida spp. }(r=0.77) \\
\text { Microsetella norvegica }(r=0.56) \\
\text { Microsetella genus }(r=0.56) \\
\text { Harpacticoids }(r=0.58)\end{array}$ \\
\hline 19 & $(34 k D a)$ & $\begin{array}{l}\text { Evadne nordmanni }(r=0.58) \\
\text { Cirripedia nauplii }(r=0.61)\end{array}$ \\
\hline 23 & $(20 \mathrm{kDa})$ & Evadne nordmanni $(r=0.63)$ \\
\hline
\end{tabular}


Table 5 (continued)

\begin{tabular}{ll}
\hline Protein band $\mathrm{n}^{\circ}$ & Correlations with 4zooplankton \\
\hline $25(15 \mathrm{kDa})$ & \\
& $\begin{array}{l}\text { Gasteropoda larvae }(r=0.60) \\
\text { Mollusca larvae }(r=0.63) \\
\text { Oithona nana females }(r=0.57)\end{array}$ \\
& $\begin{array}{l}\text { Penilia avirostris }(r=0.56) \\
\text { Acartia spp. }(r=0.59) \\
\end{array}$ \\
& Microsetella norvegica $(r=0.69)$ \\
& Microsetella genus $(r=0.70)$ \\
& Harpacticoids $(r=0.65)$
\end{tabular}

cytoskeleton proteins, above all actin, and also tubulin. Cytoskeleton proteins were also predominant in the proteome from the marine bivalve Ruditapes decussatus exposed to Cd contamination (Chora et al., 2009). Actin, one of the most abundant proteins in cell, is a fundamental component of cytoskeleton in muscular and non muscular cells (Manduzio et al., 2005). It has roles in movement, phagocytosis, endocytosis, exocytosis, vesicular transport and cellular plasticity (Thompson et al., 2011). Regarding tubulin, it is also involved in the structure and the function of the cytoskeleton (Chora et al., 2009). It has been shown evidence that cytoskeletal proteins had a role as target of metal-related oxidative stress (Rodriguez-Ortega et al., 2003). Exposure of Mytilus galloprovincialis to $\mathrm{Cu}^{2+}\left(5 \mu \mathrm{g} \mathrm{L}^{-1}\right)$ caused severe perturbations on haemocyte cytoskeletal architecture, due to disorganization of the cortical actin (Fagotti et al., 1996). Actin filaments attain different shapes and structure when exposed to $\mathrm{CuSO}_{4} 2 \mathrm{mM}$ (Kaur et al., 2011). At high concentrations (0.8-1 mM), $\mathrm{CdCl}_{2}$ caused a reversible actin denaturation (Dalle Donne et al., 1997), and in a same way, the actin down-regulation has been reported in Mytilus edulis from contaminated sites (Manduzio et al., 2005). Decrease in tubulin expression has been observed after oxidative stress (Miura et al., 2005), metal contamination inducing such stress.

In the present study, spots 1 and 4, respectively assigned to actin and tubulin, were less expressed in the most contaminated stations (spots 1 and 4 negatively correlated with $\mathrm{Cu}$ and $\mathrm{Zn}$ ). This suggests that metal stress could alter cytoskeleton protein expression from zooplankton. Different results were obtained for spots A, C and D, also assigned to actin, and however showing stronger expression in the most contaminated stations (A, C and D positively correlated with $\mathrm{Cu}, \mathrm{Pb}$ and $\mathrm{Zn}$ ). Opposite actin expressions recently have been mentioned for R. decussatus, in gill from which, actin was 8-fold upregulated after $\mathrm{Cd}$ exposure, whereas actin from the digestive gland was oppositely down-regulated, and even suppressed (Chora et al., 2009). Such changes in actin expression also have been reported for the clam Chamaelea gallina, in which two actin isoforms were respectively increased and decreased after exposure to a same contaminant treatment (Rodriguez-Ortega et al., 2003). Other studies mentioned the up-regulation of the cytoskeletal proteins actin (7.7-fold), tropomyosin (4.0-fold), myosin (2.8-fold) in the haemolymph from the oyster Saccostrea glomerata exposed to $\mathrm{Pb}$ and/or Zn (Thompson et al., 2011). Some hypothesis could explain such cytoskeleton protein up-regulation: (i) the damages caused by metal stress to cytoskeleton proteins could then induce their increased expression (Rodriguez-Ortega et al., 2003); (ii) metals could act as effective actin polymerizing agents, as shown for $\mathrm{CdCl}_{2}$ at concentrations from 0.25 to $0.6 \mathrm{mM}$ (Dalle Donne et al., 1997), since metal ions are able to affect the nucleation step of actin polymerization (Maruyama, 1981).

Spots A, C and D, assigned to actin, showed positive correlations with $\mathrm{Cu}, \mathrm{Pb}$ and $\mathrm{Zn}$, and with $\mathrm{O}$. nana (for $\mathrm{C}$ and $\mathrm{D}$ ). Another protein, calreticulin identified from spot $\mathrm{B}$, also maintained such positive
Table 6

Positive correlations (in bold) $(p<0.05)$ and relations (in italics) $(0.05<p<0.10)$ between changes in the intensities of zooplankton protein spots detected on the 2Dgels, and biomasses of zooplankton species, genera, or groups from sampling stations $S_{1}$ to $S_{13}$ in Toulon Bay. In grey, spots positively correlating with some members of zooplankton group 1 (Cladocerans and Harpacticoids). In black, spots positively correlating with some members of zooplankton group 2 (Mollusca larvae and Cyclopoids).

\begin{tabular}{ll}
\hline Protein spot $\mathrm{n}^{\circ}$ & Correlations or relations with zooplankton \\
\hline a $(31.2 \mathrm{kDa})$ & Oithona nana females $(r=0.52)$
\end{tabular}
b $(20.1 \mathrm{kDa})$
Penilia avirostris $(r=\mathbf{0 . 6 3})$
Cladocerans $(r=\mathbf{0 . 7 4})$

c

$(22.6 \mathrm{kDa})$

魚

Cyclopoida copepodites $(r=0.54)$

Oithona genus $(r=\mathbf{0 . 6 8})$

Cyclopoids $(r=\mathbf{0 . 6 1})$

Copepods $(r=0.51)$

e

$(14.5 \mathrm{kDa})$

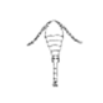

Cyclopoida copepodites $(r=0.56)$

Oithona genus $(r=0.54)$

Cyclopoids $(r=\mathbf{0 . 7 0})$

B

$(48.8 \mathrm{kDa})$ (9)

Bivalvia larvae $(r=\mathbf{0 . 6 5})$

Oithona nana $(r=\mathbf{0 . 5 6})$

Oithona nana females $(r=\mathbf{0 . 6 0})$

C

$(38.2 \mathrm{kDa})$

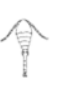

Oithona nana females $(r=\mathbf{0 . 6 2})$

D

$(38.3 k D a)$

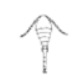

Oithona nana females $(r=0.50)$
Penilia avirostris $(r=\mathbf{0 . 6 5})$

Cladocerans $(r=0.54)$ Euterpina acutifrons $(r=0.51)$

Microsetella genus $(r=0.53)$

Euterpina acutifrons $(r=\mathbf{0 . 7 2})$

Microsetella norvegica $(r=\mathbf{0 . 8 4})$

Microsetella genus $(r=\mathbf{0 . 8 4})$

Harpacticoids $(r=\mathbf{0 . 8 4})$

Euterpina acutifrons $(r=\mathbf{0 . 6 6})$

Microsetella norvegica $(r=\mathbf{0 . 8 5})$

Microsetella genus $(r=\mathbf{0 . 8 4})$

Harpacticoids $(r=\mathbf{0 . 8 4})$

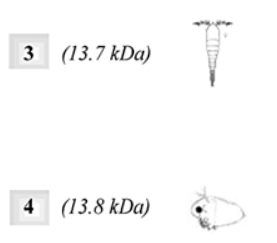

Cladocerans $(r=0.51)$

relations with 0 . nana and trace metals, Zn more precisely. As a result, actin and calreticulin could be regarded as zooplankton markers of metal stress. Calreticulin, known as an endoplasmic reticulum (ER) molecular chaperone, is an ubiquitous multifunctional calcium-binding protein (Ryu et al., 2012). Calreticulin is 

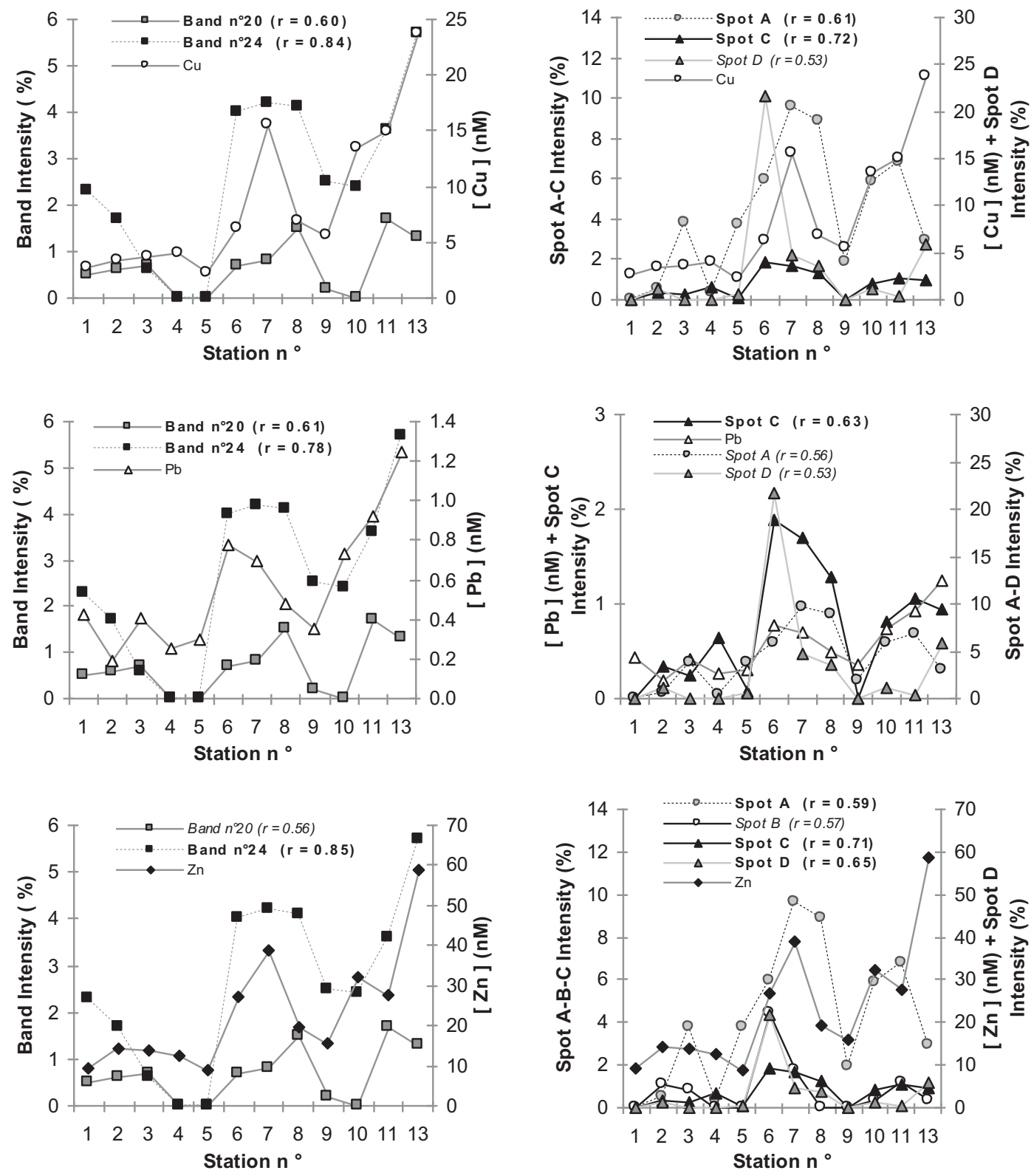

Fig. 6. On the left, positive correlations (in bold) $(p<0.05)$ and relations (in italics) $(0.05<p<0.10)$ between total dissolved trace metal concentrations (Cu, $\mathrm{Pb}$ and $\mathrm{Zn})$ in sampling stations $\mathrm{S}_{1}-\mathrm{S}_{13}$ in Toulon Bay ${ }^{*}$ and intensities of the zooplankton protein bands $\mathrm{n}^{\circ} 20$ ( $\left.30 \mathrm{kDa}\right)$ and $\mathrm{n}^{\circ} 24(15 \mathrm{kDa})$ present on the $1 \mathrm{D}$-gels. On the right, positive correlations (in bold) $(p<0.05)$ and relations (in italics) $(0.05<p<0.10)$ between total dissolved trace metal concentrations $(\mathrm{Cu}, \mathrm{Pb}$ and $\mathrm{Zn})$ in sampling stations $\mathrm{S}_{1}-\mathrm{S}_{13}$ in Toulon Bay ${ }^{*}$ and intensities of the zooplankton protein spots A, B, C and D present on the 2D-gels. "For logistic reasons, sampling for total dissolved trace metal analysis was not carried out in $\mathrm{S}_{12}$.

needed in $\mathrm{Ca}^{2+}$ buffering and in quality control process during protein synthesis and folding, in particular during refolding of misfolded proteins and ER stress responses (Leung et al., 2011). In addition to bind $\mathrm{Ca}^{2+}$, calreticulin also would be able to bind $\mathrm{Zn}^{2+}$ (Michalak et al., 1992), and calreticulin requires $\mathrm{Zn}$ for its interaction with the ERp57 thiol oxidoreductase (Leach et al., 2002). Studies showed evidence that Cd stress induced the calreticulin upregulation, in hepatopancreas of Perna viridis (Leung et al., 2011), and in leaf of Phytolacca americana (Zhao et al., 2011). As a result, it has been suggested that elevated levels of calreticulin could serve to protect the cells against Cd cytoxicity (Zhao et al., 2011). The metal stress inducing ER stress, the resulting misfolded proteins would need the up-regulation of ER chaperone, like calreticulin, to be refolded (Leung et al., 2011). Although this has not directly been shown in the present study, the possible up-regulation of structural and chaperone proteins such as actin and calreticulin in zooplankton cells could provide strength and protection to the predominant $O$. nana during the oxidative stress induced by metal contamination in LiB. In these conditions, the development of $O$. nana, and the subsequent decrease in zooplankton diversity that we observed in LiB, could be partly due to differences in protein expression.

\section{Acknowledgements}

This research was supported by the Conseil Général du Var (CG) and Toulon - Provence - Méditerranée (TPM). We are deeply indebted to Dr. Bernard Poste for his participation to 1-DE experiments, to Pr. Bruno Rossetto for his advices in statistical analysis, 
and to Dr. Soultana Zervoudaki for help during the zooplankton length-weight relationships research.

\section{Appendix A. Supplementary material}

Supplementary material associated with this article can be found, in the online version, at doi:10.1016/j.marenvres.2012.06. 004 .

\section{References}

Akimoto, H., Wu, C., Kinumi, T., Ohmiya, Y., 2004. Biological rhythmicity in expressed proteins of the marine dinoflagellate Lingulodinium polyedrum demonstrated by chronological proteomics. Biochemical and Biophysical Research Communications 315, 306-312.

Andacht, T.M., Winn, R.N., 2006. Incorporating proteomics into aquatic toxicology. In: Abstracts from 13th Int. Symp. Poll. Resp. Mar. Org. - Environ. Genomics Proteomics. Marine Environmental Research 62, S156-S186.

Bernard, G., Denis, J., Deneux, F., Belsher, T., Sauzade, D., Boudouresque, C.F., Charbonnel, E., Emery, E., Herve, G., Bonhomme, P., 2001. Etude et cartographie des biocénoses de la rade de Toulon - Rapport de synthèse final. In: Contrat d'étude pour le Syndicat Intercommunal de l'Aire Toulonnaise, Ifremer et GIS Posidonie. Ifremer Publ, La Seyne, pp. 1-150.

Bruland, K.W., Lohan, M.C., 2004. Controls of trace metals in seawater. In: Holland, H.D., Turekian, K.K. (Eds.), Treatise on Geochemistry. Elsevier Pergamon Press, pp. 23-47. Book 6

Chan, L.L., Lo, S.C.L., Hodgkiss, I.J., 2002. Proteomic study of a model causative agent of harmful algal blooms, Prorocentrum triestinum I: optimization of sample preparation methodologies for analyzing with two-dimensional electrophoresis. Proteomics 2, 1169-1186.

Chan, L.L., Hodgkiss, I.J., Lu, S., Lo, S.C.L., 2004. Use of two-dimensional gel electrophoresis proteome reference maps of dinoflagellates for species recognition of causative agents of harmful algal blooms. Proteomics 4, 180-192.

Chan, L.L., Hodgkiss, I.J., Lam, P.K.S., Wan, J.M.F., Chou, H.N., Lum, J.H.K., Lo, M.G.Y., Mak, A.S.C., Sit, W.H., Lo, S.C.L., 2005. Use of two-dimensional gel electrophoresis to differentiate morphospecies of Alexandrium minutum, a paralytic shellfish poisoning toxin-producing dinoflagellate of harmful algal blooms. Proteomics 5, 1580-1593.

Chan, L.L., Sit, W.H., Lam, P.K.S., Hsieh, D.P.H., Hodgkiss, I.J., Wan, J.M.F., Ho, A.Y.T.H., Choi, N.M.C.C., Wang, D.Z., Dudgeon, D., 2006. Identification and characterization of a "biomarker of toxicity" from the proteome of the paralytic shellfish toxin-producing dinoflagellate Alexandrium tamarense. Proteomics 6, 654-666.

Chisholm, L.A., Roff, J.C., 1990. Size-weight relationships and biomass of tropical neritic copepods off Kingston, Jamaica. Marine Biology 106, 71-77.

Chora, S., Starita-Geribaldi, M., Guigonis, J.-M., Samson, M., Roméo, M., Bebianno, M.-J., 2009. Effect of Cd in the clam Ruditapes decussatus assessed by proteomic analysis. Aquatic Toxicology 94, 300-308.

Daley, D.O., 2008. The assembly of membrane proteins into complexes. Current Opinion in Structural Biology 18, 420-424.

Dalle Donne, I., Milzani, A., Colombo, R., 1997. Actin assembly by cadmium ions. Biochimica et Biophysica Acta 1357, 5-17.

Dong, H.P., Wang, D.Z., Dai, M., Hong, H.S., 2010. Characterization of particulate organic matters in the water column of the South China Sea using a shotgun proteomic approach. Limnology and Oceanography 55 (4), 1565-1578.

Fagotti, A., Di Rosa, I., Simoncelli, F., Pipe, R.K., Panara, F., Pascolini, R., 1996. Effects of copper on actin and fibronectin organization in Mytilus galloprovincialis haemocytes. Developmental and Comparative Immunology 20, 383-391.

Fernandez de Puelles, M.L., Alemany, F., Jansa, J., 2007. Zooplankton time-series in the Balearic Sea (Western Mediterranean): variability during the decade 1994-2003. Progress in Oceanography 74, 329-354.

Gaudy, R., Youssara, F., Diaz, F., Raimbault, P., 2003. Biomass, metabolism and nutrition of zooplankton in the Gulf of Lions (NW Mediterranean). Oceanologica Acta 26, 357-372.

Hansen, B.H., Altin, D., Nordtug, T., Olsen, A.J., 2007. Suppression substractive hybridization library prepared from the copepod Calanus finmarchicus exposed to a sublethal mixture of environmental stressors. Comparative Biochemistry and Physiology D 2, 250-256.

Herbelin, A.L., Westall, J.C., 1999. FITEQL 4.0: A Computer Program for Determination of Chemical Equilibrium Constants from Experimental Data. Report 99-01. Department of Chemistry, Oregon State University, Corvallis.

Hirose, K., 2007. Metal-organic matter interaction: ecological roles of ligands in oceanic DOM. Applied Geochemistry 22, 1636-1645.

Huang, H.Q., Xiao, Z.Q., Lin, Q.M., Chen, P., 2005. Characteristics of trapping various organophosphorus pesticides with a ferritin reactor of shark liver (Sphryna zygaena). Analytical Chemistry 77, 1920-1927.

Ifremer, 2010. Bulletin de la Surveillance de la Qualité du Milieu Marin Littoral. Edition 2010. Résultats acquis jusqu'en 2009. Ifremer/RST.LER/PAC/10-04/. Laboratoire Environnement Ressources de Provence Azur Corse, 89 p.

Isinibilir, M., Kideys, A.E., Tarkan, A.N., Yilmaz, I.N., 2008. Annual cycle of zooplankton abundance and species composition in Izmit Bay (the northeastern Marmara Sea). Estuarine Coastal and Shelf Science 78, 739-747.
Jamet, J.L., Boge, G., Richard, S., Geneys, C., Jamet, D., 2001. The zooplankton community in bays of Toulon area (northwest Mediterranean Sea, France). Hydrobiologia 457, 155-165.

Jamet, J.L., Jean, N., Boge, G., Richard, S., Jamet, D., 2005. Plankton succession assemblage structure in two neighbouring littoral ecosystems in the north-west Mediterranean Sea. Marine and Freshwater Research 56, 69-83.

Johnson, S.C., Browman, H.I., 2007. Theme section: Introducing genomics, proteomics and metabolomics in marine ecology. Marine Ecology Progress Series 332, $247-248$.

Jones, V., Ruddell, C.J., Wainwright, G., Rees, H.H., Jaffé, R., Wolff, G.A., 2004. Onedimensional and two-dimensional polyacrylamide gel electrophoresis: a tool for protein characterization in aquatic samples. Marine Chemistry 85, 63-73.

Kaur, H., Kumar, S., Singh, K., Bharadwaj, L.M., 2011. Divalent cation induced actin ring formation. International Journal of Biological Macromolecules 48, 793-797.

Kimmel, D.G., Bradley, B.P., 2001. Specific protein responses in the calanoid copepod Eurytemora affinis (Poppe, 1980) to salinity and temperature variation. Journal of Experimental Marine Biology and Ecology 266, 135-149.

Lacerda, C.M., Choe, L.H., Reardon, K.F., 2007. Metaproteomic analysis of a bacterial community response to cadmium exposure. Journal of Proteome Research 6, 1145-1152.

Laemmli, U.K., 1970. Cleavage of structural proteins during the assembly of the head of bacteriophage T4. Nature 227, 680-685.

Leach, M.R., Cohen-Doyle, M.F., Thomas, D.Y., Williams, D.B., 2002. Localization of the lectin, ERp57 binding, and polypeptide binding sites of calrexin and calreticulin. Journal of Biological Chemistry 277, 29686-29697.

Lee, F.W.F., Lo, S.C.L., 2008. The use of Trizol reagent (phenol/guanidine isothiocyanate) for producing high quality two-dimensional gel electrophoretograms (2-DE) of dinoflagellates. Journal of Microbiological Methods 73, 26-32.

Leung, P.T.Y., Wang, Y., Mak, S.S.T., Ng, W.C., Leung, K.M.Y., 2011. Differential proteomic responses in hepatopancreas and adductor muscles of green lipped mussel Perna viridis to stresses induced by cadmium and hydrogen peroxide. Aquatic Toxicology 105, 49-61.

Ling, X.P., Zhu, J.Y., Huang, L., Huang, H.Q., 2009. Proteomic changes in response to acute cadmium toxicity in gill tissue of Paralichthys olivaceus. Environmental Toxicology and Pharmacology 27, 212-218.

Lopez, J.L., 2007. Applications of proteomics in marine ecology. Marine Ecology Progress Series 332, 275-279.

Louis, Y., Garnier, C., Lenoble, V., Mounier, S., Cukrov, N., Omanović, D., Pižeta, I., 2009a. Kinetic and equilibrium studies of copper-dissolved organic matter complexation in water column of the stratified Krka River estuary (Croatia). Marine Chemistry 114, 110-119.

Louis, Y., Garnier, C., Lenoble, V., Omanović, D., Mounier, S., Pižeta, I., 2009b. Characterisation and modelling of marine dissolved organic matter interactions with major and trace cations. Marine Environmental Research 67, 100-107.

Lowry, O.H., Rosebrough, N.J., Farr, A.L., Randall, R.J., 1951. Protein measurement with the Folin phenol reagent. Journal of Biological Chemistry 193, 265-275.

Manduzio, H., Cosette, P., Gricourt, L., Jouenne, T., Lenz, C., Andersen, O.K. Leboulenger, F., Rocher, B., 2005. Proteome modifications of blue mussel (Mytilus edulis L.) gills as an effect of water pollution. Proteomics 5, 4958-4963.

Maruyama, K., 1981. Effects of trace amounts of $\mathrm{Ca}^{2+}$ and $\mathrm{Mg}^{2+}$ on the polymerization of actin. Biochimica et Biophysica Acta - Protein Structure 667, 139-142.

Michalak, M., Milner, R.E., Burns, K., Opas, M., 1992. Calreticulin. Biochemical Journal 285, 681-692.

Millero, F.J., Woosley, R., Ditrolio, B., Waters, J., 2010. Effect of ocean acidification on the speciation of metals in seawater. Oceanography $22,72-85$.

Morley, N.H., Burton, J.D., Tankere, S.P.C., Martin, J.M., 1997. Distribution and behaviour of some dissolved trace metals in the western Mediterranean Sea. Deep Sea Research II 44, 675-691.

Mosquera, E., Lopez, J.L., Alvarez, G., 2003. Genetic variability of the marine mussel Mytilus galloprovincialis assessed using two-dimensional electrophoresis. Heredity 90, 432-442.

Miura, Y., Kano, M., Abe, K., Urano, S., Suzuki, S., Toda, T., 2005. Age-dependent variations of cell response to oxidative stress: proteomic approach to protein expression and phosphorylation. Electrophoresis 26, 2786-2796.

Nunn, B.L., Timperman, A.T., 2007. Marine proteomics. Marine Ecology Progress Series 332, 281-289.

O'Farrell, P.H., 1975. High resolution two-dimensional electrophoresis of proteins. Journal of Biological Chemistry 250, 4007-4021.

Omanović, D., Kwokal, Ž, Goodwin, A., Lawrence, A., Banks, C.E., Compton, R.G., Komorsky-Lovrić, Š, 2006. Trace metal detection in Šibenik bay, Croatia: cadmium, lead and copper with anodic stripping voltammetry and manganese via sonoelectrochemistry: a case study. Journal of Iranian Chemistry Society 3, 128-139.

Omori, M., 1969. Weight and chemical composition of some important oceanic zooplankton in the North Pacific Ocean. Marine Biology 3, 4-10.

Page, D., Gouble, B., Valot, B., Bouchet, J.P., Callot, C., Kretzschmar, A., Causse, M., Renard, C.M., Faurobert, M., 2010. Protective proteins are differentially expressed in tomato genotypes differing for their tolerance to low-temperature storage. Planta 232, 483-500.

Pandhal, J., Wright, P.C., Biggs, C.A., 2007. A quantitative proteomic analysis of light adaptation in a globally significant marine cyanobacterium Prochlorococcus marinus MED4. Journal of Proteome Research 6, 996-1005. 
Poirier, I., Jean, N., Guary, J.C., Bertrand, M., 2008. Responses of the marine bacterium Pseudomonas fluorescens to an excess of heavy metals: physiological and biochemical aspects. The Science of the Total Environment 406, 76-87.

Riandey, V., Champalbert, G., Carlotti, F., Taupier - Letage, I., Thibault - Botha, D., 2005. Zooplankton distribution related to the hydrodynamic features in the Algerian Basin (western Mediterranean Sea) in summer 1997. Deep Sea Research I 52, 2029-2048.

Richard, S., Jamet, J.L., 2001. An unusual distribution of Oithona nana GIESBRECHT (1892) (Crustacea: Cyclopoida) in a Bay: the case of Toulon Bay (France, Mediterranean Sea). Journal of Coastal Research 17, 957-963.

Rodhouse, P.G., Roden, C.M., 1987. Carbon budget for a coastal inlet in relation to intensive cultivation of suspension-feeding bivalve molluscs. Marine Ecology Progress Series 36, 225-236.

Rodriguez-Ortega, M.J., Grosvik, B.E., Rodriguez-Ariza, A., Goksoyr, A., LopezBarea, J., 2003. Changes in protein expression profiles in bivalve molluscs (Chamaelea gallina) exposed to four model environmental pollutants. Proteomics 3, 1535-1543.

Ronzitti, G., Milandri, A., Scortichini, G., Poletti, R., Rossini, G.P., 2008. Protein markers of algal toxin contamination in shellfish. Toxicon 52, 705-713.

Rossi, N., 2008. Ecologie des communautés planctoniques méditerranéennes et étude des métaux lourds $(\mathrm{Cu}, \mathrm{Pb}, \mathrm{Cd})$ dans différents compartiments de deux écosystèmes côtiers (Toulon, France). Ph.D. thesis, Université du Sud Toulon Var, La Garde, France.

Ryu, S.Y., Hong, G.U., Kim, D.Y., Ro, J.Y., 2012. Enolase 1 and calreticulin regulate the differentiation and function of mouse mast cells. Cellular Signalling 24, 60-70.

Saijo, S., Tanoue, E., 2004. Characterization of particulate proteins in Pacific surface waters. Limnology and Oceanography 49, 953-963.

Shannon, C.E., Weaver, W., 1949. The Mathematical Theory of Communication. Univ of Illinois Press, Urbana, IL.

Sunda, W.G., Tester, P.A., Huntsman, S.A., 1987. Effects of cupric and zinc ion activities on the survival and reproduction of marine copepods. Marine Biology 94, 203-210.

Tanoue, E., 1996. Characterization of the particulate protein in Pacific surface waters. Journal of Marine Research 54, 967-990.

Tanoue, E., Ishii, M., Midorikawa, T., 1996. Discrete and particulate proteins in oceanic waters. Limnology and Oceanography 41, 1334-1343.
Tartarotti, B., Torres, J.J., 2009. Sublethal stress: impact of solar UV radiation on protein synthesis in the copepod Acartia tonsa. Journal of Experimental Marine Biology and Ecology 375, 106-113.

Tessier, E., Garnier, C., Mullot, J.-U., Lenoble, V., Arnaud, M., Raynaud, M., Mounier, S. 2011. Study of the spatial and historical distribution of sediment inorganic contamination in the Toulon Bay (France). Marine Pollution Bulletin 62 2075-2086.

Thompson, E.L. Taylor, D.A. Nair, S.V., Birch, V., Haynes, P.A, Raftos, D.A, 2011 A proteomic analysis of the effects of metal contamination on Sydney Rock Oyster (Saccostrea glomerata) haemolymph. Aquatic Toxicology 103, 241-249.

Van der Lee, J., De Windt, L., 2000. CHESS Tutorial and Cookbook. User's guide Nr. LHM/RD/99/05. CIG - Ecole des Mines de Paris, Fontainebleau, France.

Wang, D.Z., Lin, L., Gu, H.F., Chan, L.L., Hong, H.S., 2008. Comparative studies on morphology, ITS sequence and protein profile of Alexandrium tamarense and A. catenella isolated from the China Sea. Harmful Algae 7, 106-113.

Wang, D.Z., Dong, H.P., Xie, Z.X., Dai, M.H., Hong, H.S., 2011. Metaproteomic characterization of dissolved organic matter in the water column of the South China Sea. Limnology and Oceanography 56, 1641-1652.

Westall, J.C., Zachary, J.L., Morel, F., 1976. MINEQL, a Computer Program for the Calculation of Chemical Equilibrium Composition of Aqueous Systems. Parsons, R.M., Laboratory Technical Note 18. Massachusetts Institute of Technology, Cambridge, MA

Wilmes, P., Bond, P.L., 2004. The application of two-dimensional polyacrylamide gel electrophoresis and downstream analysis to a mixed community of prokaryotic microorganisms. Environmental Microbiology 6, 911-920.

Yilmaz, A.Z., Besiktepe, S., 2010. Annual variations in biochemical composition of size fractionated particulate matter and zooplankton abundance and biomass in Mersin Bay, NE Mediterranean Sea. Journal of Marine Systems 81, 260-271.

Zhao, L., Sun, Y.L., Cui, S.X., Chen, M., Yang, H.M., Liu, H.M., Chai, T.Y., Huang, F., 2011 Cd-induced changes in leaf proteome of the hyperaccumulator plant Phytolacca americana. Chemosphere 85, 56-66.

Zhu, J.Y., Huang, H.Q., Bao, X.D., Lin, Q.M., Cai, Z., 2006. Acute toxicity profile of cadmium revealed by proteomics in brain tissue of Paralichthys olivaceus: potential role of transferring in cadmium toxicity. Aquatic Toxicology 78 , 127-135. 